Marquette University

e-Publications@Marquette

\title{
When Managers Bypass Shareholder Approval of Board Appointments: Evidence from the Private Security Market
}

Matteo Arena

Marquette University, matteo.arena@marquette.edu

Stephen P. Ferris

University of Missouri - Columbia

Accepted version. Journal of Corporate Finance, Vol. 13, No. 4 (September 2007): 485-510. DOI. (C) 2007 Elsevier. Used with permission.

NOTICE: this is the author's version of a work that was accepted for publication in Journal of Corporate Finance. Changes resulting from the publishing process, such as peer review, editing, corrections, structural formatting, and other quality control mechanisms may not be reflected in this document. Changes may have been made to this work since it was submitted for publication. A definitive version was subsequently published in Journal of Corporate Finance, [VOL 13, ISSUE 14, September 2007] DOI. 


\title{
When Managers Bypass Shareholder Approval of Board Appointments: Evidence from the Private Security Market ${ }^{\diamond}$
}

\author{
Matteo P. Arena ${ }^{a}{ }^{*}$ \\ Department of Finance, Marquette University \\ Milwaukee, WI \\ Stephen P. Ferris ${ }^{b}, 1$ \\ Department of Finance, University of Missouri-Columbia \\ Columbia, MO
}

\begin{abstract}
This paper investigates the influence of managerial entrenchment on private placements by examining the firm's decision to appoint representatives of the private investors to the board without shareholder approval. By analyzing a sample of U.S. firms that appoint directors in combination with private offerings between 1995 and 2000, we find that firms with greater managerial entrenchment are more likely to bypass shareholder approval. Firms that bypass shareholders are less likely to appoint independent directors or to elect one of these directors as chairman. We also show that the market reacts more positively to the private offering announcement when the firm submits its board candidates for shareholder approval. Further, firms that bypass approval underperform compared to firms that obtain it. Overall our findings suggest that managers avoid shareholder approval to perpetuate entrenchment.
\end{abstract}


NOT THE PUBLISHED VERSION; this is the author's final, peer-reviewed manuscript. The published version may be accessed by following the link in the citation at the bottom of the page.

\section{Introduction}

The conventional view of private equity placements as a mechanism to enhance external monitoring has been recently challenged by studies arguing that managers can use private placements to promote their own entrenchment (i.e., Wu (2004) and Barclay et al. (2007-this issue)). In this paper we contribute to the debate over the governance implications of private placements by analyzing a heretofore unexamined aspect of that process. Specifically, we examine the decision to appoint representatives of private investors to the firm's board of directors without a vote of the shareholders.

Wruck (1989) finds that private placements in which investors are appointed to the board are characterized by significantly lower announcement period returns. She conjectures that the appointment of these individuals without shareholder approval might be the cause of the lower returns. This study tests her conjecture and provides an estimate of value of shareholder participation in the selection of a firm's board of directors. Such analysis has important implications for corporate governance, especially in environments where super-voting rights might exist or external equity investors are otherwise disadvantaged.

Our analysis of the circumvention of shareholder approval for the appointment of directors also contributes to a continuing policy debate regarding the extent of shareholder power in the director election process and the role of independent directors. Even though a 2003 SEC proposal on this issue stalled due to the opposition of senior industry executives, by early 2006 some firms have implemented changes in their bylaws to increase shareholder power during the director election process. These changes are consistent with the position advocated by activist shareholders and various legal academics. ${ }^{2}$ Further, since this research examines the effects resulting from the nullification of a basic shareholder right, it benchmarks the impact that violation, of one share-one vote rules might have on firms in countries with weak protection of shareholder interests. Wruck (1989) suggests that the appointment of directors without shareholder approval at the time of a private offering might imply managerial entrenchment. According to this view, managers bypass shareholders and appoint to the board individuals who are aligned with current management and unlikely to provide independent monitoring.

Journal of Corporate Finance, Vol. 13, No. 4 (September 2007): pg. 485-510. DOI. This article is @ Elsevier and permission has been granted for this version to appear in e-Publications@Marquette. Elsevier does not grant permission for this article to be further copied/distributed or hosted elsewhere without the express permission from Elsevier. 
Such directors are likely to be less effective monitors than those who are regularly elected by shareholders. Barclay et al. (2007-this issue) and Wu (2004) argue that firms are more likely to privately place securities with investors who promise to vote their shares in managers' favor and consequently protect managers' positions. If true, this is more likely to occur when firms assign directorships to representatives of these private investors. As long as entrenched managers estimate the probability that shareholders will oppose their slate of board candidates to be greater than zero, they will more likely circumvent the shareholder election process to appoint "friendly" investors to the board. ${ }^{3}$ We call this the entrenchment hypothesis.

Berle and Means (1932) and more recently Demb and Neubauer (1992) and Lorsch (1989), question the importance of shareholder voting for directors since the firm's proxy committee is appointed by the existing management and the proxy slate is usually elected, resulting in management virtually "dictating their own successors". Although state corporate law requires that shareholders select the board of directors, DeAngelo and DeAngelo (1989) observe that even in the extreme case of a proxy fight, shareholders win board seats only one-third of the time. Bebchuck (2003) contends that shareholders seeking to exercise their right to replace directors face substantial obstacles and that, apart from hostile takeovers, the incidence of shareholder challenges to directors is negligible. Since shareholders virtually always vote for management's slate of candidates, managers might estimate the probability that shareholders will reject their slate of candidates to be zero. If true, managers do not need to circumvent shareholders to perpetuate entrenchment, and the firm's decision to bypass shareholders would not be symptomatic of weak corporate governance. We call this the approval irrelevance hypothesis.

A third possibility might be that managers bypass shareholder approval when private investors demand immediate board representation as a condition for providing capital because of concern about managerial exploitation of firm resources and consumption of agency perquisites. If true, companies that bypass shareholder approval might be characterized ex-ante by poor corporate governance, but will more likely increase the monitoring quality of the board at the time of the private placement. We call this the monitoring hypothesis. ${ }^{4}$

Journal of Corporate Finance, Vol. 13, No. 4 (September 2007): pg. 485-510. DOI. This article is (C) Elsevier and permission has been granted for this version to appear in e-Publications@Marquette. Elsevier does not grant permission for this article to be further copied/distributed or hosted elsewhere without the express permission from Elsevier. 
We test these three competing hypothesis by analyzing a sample of U.S. firms that appoint directors in combination with private offerings between 1995 and 2000. We find that firms in which managers are entrenched are more likely to bypass shareholder approval of board appointments at the time of the private placement. Firms that bypass shareholders are less likely to appoint independent directors or to elect a new independent director as chairman of the board. We also find that the stock market reacts more positively to the announcement of the private offering when the firm submits board candidates for shareholder approval. Further, we show that firms that bypass shareholder approval significantly underperform after the private offering compared to firms that obtain shareholder approval. We conclude from our findings that the firm's decision to circumvent shareholder ratification is most consistent with the entrenchment hypothesis.

\section{The role of shareholder voting in corporate governance}

The right of shareholders to vote for the members of the board of directors provides an important connection between ownership and control. As described by Fama and Jensen (1983), ratification and monitoring are two important steps in the decision process of a corporation. The approval of directorships by the shareholders is a fundamental element of these ratification and monitoring steps. Shareholder voting rights are considered by the financial contracting literature as a valid alternative to contracts. Grossman and Hart (1986), Hart and Moore (1988) and Hart and Moore (1990) contend that contracts cannot specify all future contingencies and that voting rights might offer a partial remedy since they can be used to ratify decisions ex-post. Moreover, Aghion and Bolton (1992) and Kaplan and Stromberg (2003) note that voting rights can shift between managers and outside investors depending on the firm's financial performance.

Even though shareholder voting to approve board proposals is a fundamental shareholder right, does it make a difference? Berle and Means (1932) argue that diffuse ownership decreases shareholder incentive to vote or to otherwise attempt to influence corporate decisions, thus resulting in the approval of management proposals in most circumstances. Alternatively, Easterbrook and Fischel (1983) 
argue that shareholder voting rights are an effective monitoring tool. Bethel and Gillan (2002) show that for non-routine proposals (i.e., when brokers cannot vote on behalf of shareholders) a larger number of votes is cast against management. However routine management proposals are usually ratified, providing managers with the incentive to classify a proposal as "routine" to increase the likelihood of approval. Burch et al. (2004) analyze acquiring firm merger proxies and find that many deals are only narrowly approved, suggesting that shareholder voting rights are not merely perfunctory. Balachandran et al. (2004) empirically analyze the causes and consequences of shareholder voting rights and find that firms with poor performance and weak internal governance tend to adopt equity-based compensation plans without shareholder approval. These firms also tend to continue their poor performance even after the adoption of the compensation plan.

\section{How do firms appoint directors without shareholder approval?}

Firms that plan to issue securities privately and appoint representatives of these private purchasers to the board might ask for shareholder approval of the security issuance as well as the director nominees. Even though this study focuses on shareholder approval of the directorships, we also consider the approval of the security issuance since in the context of private offerings these are often related actions.

\subsection{Private security issuance without shareholder approval}

If the number of authorized common shares in the firm's certificate of incorporation is larger than the number of shares outstanding, the firm can issue common stock without shareholder approval unless required by the listing exchange. Moreover, a firm can issue convertible preferred shares without shareholder approval if it has a blank check preferred stock provision in its certificate of incorporation. A blank check preferred stock provision gives directors the discretion to issue preferred stock with particular voting, dividend, conversion and other rights without shareholder approval. Firms without such a provision in their charter can issue a new class of preferred stock only with shareholder approval. A company might also

Journal of Corporate Finance, Vol. 13, No. 4 (September 2007): pg. 485-510. DOI. This article is @ Elsevier and permission has been granted for this version to appear in e-Publications@Marquette. Elsevier does not grant permission for this article to be further copied/distributed or hosted elsewhere without the express permission from Elsevier. 
avoid shareholder approval by issuing convertible notes instead of common equity or preferred stock since convertible notes do not require shareholder approval at the time of the issue. ${ }^{5}$

There are cases, however, in which the listing exchange requires shareholder approval even when the common shares are already authorized, a blank check preferred stock provision is present in the certificate of incorporation, or convertible notes are issued. The New York Stock Exchange, NASDAQ, and AMEX require shareholder approval when the issuance of common stock or securities exercisable or convertible into common stock is at least $20 \%$ of the common stock or at least $20 \%$ of the voting power outstanding prior to the issuance and is sold for less than the greater of book or market value of the stock. ${ }^{6}$

\subsection{Board appointments without shareholder approval}

Usually the bylaws of a corporation do not require a specific number of directors. More typically, they indicate a range such as "the board of directors shall consist of no less than five, and no more than ten members". In this case, the existing directors can add new directors to the board without shareholder approval and without amending the bylaws. If the addition of the new directors increases the board size beyond the upper limit, the board can usually increase the maximum number of directors without shareholder approval by amending the bylaws. ${ }^{7}$

Another method that allows the appointment of directors without shareholder approval is by replacement. The resignation of a director creates a vacancy on the board that can be filled by a new director without approval from shareholders. Firms can use these two methods independently from a private offering to obtain the appointments they seek. Firms, however, typically use these stratagems in connection with private placements.

A strategy to bypass shareholders that requires the private placement of securities can be implemented by issuing blank check preferred securities, such as convertible preferred shares, that allow investors to elect one or more directors. If a blank check preferred stock provision is already present in the charter, no approval is required to issue these securities. Although directors would have the right to bypass shareholder approval under these conditions, the

Journal of Corporate Finance, Vol. 13, No. 4 (September 2007): pg. 485-510. DOI. This article is @ Elsevier and permission has been granted for this version to appear in e-Publications@Marquette. Elsevier does not grant permission for this article to be further copied/distributed or hosted elsewhere without the express permission from Elsevier. 
decision to do so must be weighed against their fiduciary responsibilities towards shareholders. ${ }^{8}$

The duration over which shareholder approval of board nominees is denied varies. Private purchasers of convertible securities often have the special right to elect a certain number of directors separately from common shareholders. In this case, shareholders are circumvented indefinitely. If, however, the board adds new directors because of the flexibility provided by the bylaws and the private purchasers lack special voting rights, common shareholders must ratify these appointments by election in a subsequent annual meeting. If the board is not staggered, the election occurs not later than twelve months after the private placement; if the board is staggered, shareholders might have to wait as long as three years before voting to ratify the directors' appointments.

It is also important to note that the approval of board appointments in connection with private placements is more discretionary than the approval of securities. For example, exchange rules require shareholder approval of security issuances as described earlier, but do not require the approval of directors. In essence, a firm that asks shareholders to approve the private offering of new securities does so because it is required, but a firm that asks shareholders to approve the appointment of new directors in connection with a private placement does so voluntarily.

\subsection{The relation between approval of security issuance and approval of board appointments}

The approval of securities and the approval of board appointments are sometimes interrelated. If a firm does not have a blank check preferred stock provision in its charter, it must ask for shareholder approval to issue preferred convertible shares. In the proxy sent to investors, the company usually specifies the rights associated with these securities. One of these rights might be the right of preferred convertible stockholders to elect one or more directors in addition to the directors regularly elected by common shareholders. In this case, shareholders approve the issuance of convertible preferred shares, while simultaneously permitting the firm and the private investors to appoint directors.

When firms decide to privately issue more than $20 \%$ of their fully diluted common stock and ask authorization from shareholders as

Journal of Corporate Finance, Vol. 13, No. 4 (September 2007): pg. 485-510. DOI. This article is (C Elsevier and permission has been granted for this version to appear in e-Publications@Marquette. Elsevier does not grant permission for this article to be further copied/distributed or hosted elsewhere without the express permission from Elsevier. 
required by exchange rules, they often simultaneously declare their intention to appoint directors and report the names of the appointees in the proxy. In such case, the firm's shareholders implicitly approve the board appointments when they vote in favor of the private offering.

A firm can circumvent the exchange rules that require shareholder approval by issuing less than $20 \%$ of the common stock. In this case, the firm does not have to submit the security issuance and the director nominees for shareholder approval. A few months later, the firm asks for shareholder approval to sell the remaining amount of equity it desires. The directors, however, are already appointed and do not require shareholder approval.

\section{Data and sample characteristics}

\subsection{A sample construction}

We search Factiva for press releases that announce private placements associated with board appointments for U.S. firms between January 1995 to December 2000. We identify 185 placements distributed over 181 unique firms that are covered by both CRSP and Compustat at the time of the offering. For the four firms that privately issue securities and grant directorships twice in our sample period, we remove the second placement from our sample to eliminate potential autocorrelation in our multivariate analysis. We collect issue characteristics from 8-K and SC-13D filings, board characteristics, insider ownership, and blockholder ownership from proxy statements, institutional ownership from Compact Disclosure, accounting data from Compustat, and stock prices and returns from CRSP. We list all variables and their definitions in the Appendix.

We determine if a firm asks for shareholder approval of board appointments in connection with the private placement by examining press releases, 8-K filings, and proxy statements. A firm can seek shareholder approval for its board candidates in two ways. First, the firm can place representatives of the private investor on the slate for the annual meeting election that follows the date of the private placement. Alternatively, if the firm issues preferred stock but needs to ask for shareholder approval because of the absence of a blank check preferred stock provision, it may specify in the proxy the right of preferred stockholders to elect directors in addition to those elected by common shareholder. When common shareholders then approve the 
NOT THE PUBLISHED VERSION; this is the author's final, peer-reviewed manuscript. The published version may be accessed by following the link in the citation at the bottom of the page.

preferred stock issuance, they also approve the appointment of directors by the private investors.

\subsection{Sample characteristics}

As reported in Panel A of Table 1, the majority of the sample firms trade on NASDAQ (74.6\%). Fisher's exact test of homogeneity shows that firms asking for shareholder approval of board appointments differ significantly in their distribution across stock exchanges from firms not asking for shareholder approval. Firms that trade on the NYSE are more likely to seek approval (29.4\% versus $9.5 \%)$

Panels B through $\mathrm{F}$ of Table 1 examine various characteristics of our sample security issuances. The securities offered in the private placements are generally common shares (38.4\%) and convertible preferred shares (42.2\%). The majority of the private security issues in our sample is not approved by shareholders $(65.7 \%)$, and has private equity firms as the private purchasers $(60.0 \%)$. Almost half of the offerings are associated with one board appointment (49.2\%), but not infrequently, private issues are connected with radical board restructurings. Indeed, seven placements in our sample are associated with the appointment of five or more directors. In most cases, firms increase the size of their boards by appointing additional directors $(63.2 \%)$. In $28 \%$ of the cases, however, firms replace some of the existing directors with representatives of the private investors. This form of board restructuring does not change the size of the board. In a few cases $(8.6 \%)$, firms simultaneously replace and add directors.

The most noticeable difference between the approval/nonapproval subsamples is that firms that issue convertible preferred shares and appoint a larger number of directors are more likely to seek shareholder approval for their appointments. As mentioned in Section 4.1, firms without a blank check provision in their charters that desire to issue preferred shares with special rights typically present the security issuance agreement in the proxy and submit it to the vote of shareholders. Common shareholders approve the right of preferred shareholders to appoint directors at the time they ratify the issuance of the preferred shares since that is one of the rights specified in the proxy. This particular approval mechanism explains why a higher percentage of convertible preferred share issues is associated with shareholder approval of board appointments. As shown by Panel C of

Journal of Corporate Finance, Vol. 13, No. 4 (September 2007): pg. 485-510. DOI. This article is @ Elsevier and permission has been granted for this version to appear in e-Publications@Marquette. Elsevier does not grant permission for this article to be further copied/distributed or hosted elsewhere without the express permission from Elsevier. 
Table 1, firms that ask for shareholder approval of privately placed securities are also more likely to seek shareholder approval of board appointments.

In Table 2 we present the mean (median) value of firm characteristics, issue characteristics, governance, and past performance variables for the full sample as well as the approval/nonapproval subsamples. The mean (median) value of total assets for the full sample is $\$ 217.0$ million ( $\$ 47.3$ million), and the mean (median) market capitalization is $\$ 182.8$ million ( $\$ 53.4$ million). The mean (median) age, measured as the number of years that elapse between the date of the CRSP listing and the issue date, is 6.17 years (4.14 years). These results are consistent with Wu (2004) who observes that firms that privately place securities usually have just recently gone public and are still small.

Our measure of free cash flow is calculated as in Lehn and Poulsen (1989) and standardized by total assets (Freecash/assets). The mean (median) of Freecash/assets is $-\$ 0.23$ million $(-\$ 0.04$ million), indicating that about half of our sample firms have negative free cash flow.

On average, the fraction of common shares privately placed is $26 \%$. The gross proceeds have a mean (median) of $\$ 46.74$ million (\$10 million). The fraction of shares placed is larger than those presented by Wruck (1989), Hertzel and Smith (1993), and Wu (2004) for two possible reasons. First, we include in our sample only private placements associated with board appointments which, ceteris paribus, are expected to be larger in size than private placements not associated with board appointments. Second, we calculate the fraction placed by converting all convertible securities distributed to private investors, including warrants, into common stock.

We find that, on average, firms appoint 1.89 directors at the time of the private placement; this changes the composition of $25 \%$ of the board. The mean (median) board size is 6.53 (6). The small size of the board of directors for the average firm in our sample is not surprising given the small size and youth of our sample firms. The CEO is also the chairman of the board in slightly more than half of the sample firms (54\%). The CEO is the founder of $33 \%$ of the sample firms. In $68 \%$ of the sample firms the chairman is one of the top managers. On average, insiders hold $32 \%$ of the board seats and own

Journal of Corporate Finance, Vol. 13, No. 4 (September 2007): pg. 485-510. DOI. This article is (C Elsevier and permission has been granted for this version to appear in e-Publications@Marquette. Elsevier does not grant permission for this article to be further copied/distributed or hosted elsewhere without the express permission from Elsevier. 
$22 \%$ of the outstanding shares of the company. Institutional investors, on average, own $20 \%$ of the firm's outstanding shares.

The summary statistics relative to past performance presented in Panel D suggest that, on average, the firms in our sample tend to underperform in the year prior to the private placement. Both the average return on assets for the fiscal year preceding the year of the private placement, and the buy-and-hold abnormal stock returns for the year preceding the private placement are negative $(-0.31$ and $17 \%$, respectively). After correcting for the industry median, $Q$ has a positive mean (1.02), but a negative median $(-0.06)$.

The results presented in Table 2 reveals a number of differences between firms seeking and firms circumventing shareholder approval of board appointments. Firms that do not ask for approval are significantly smaller, younger, distribute a lower portion of equity to private investors in exchange for a smaller dollar amount, and appoint a smaller number of directors. The two subsamples also differ along a variety of governance dimensions. Firms that circumvent shareholder approval of board appointments are characterized by a smaller board prior to the placement, are more likely to have an insider as chairman, have a higher proportion of insiders on the board, and have a lower percentage of the outstanding equity owned by institutional investors. Aside from board size, these differences in governance characteristics are consistent with the hypothesis that entrenched managers are more likely to avoid shareholder approval of board appointments at the time of a private offering.

The only performance variable that is significantly different between the two subsamples is $Q$. Firms that ask for shareholder approval are characterized by a lower $Q$ in the year preceding the issue. Since $Q$ is also a measure of growth opportunities, and the firms in the approval subsample are significantly larger and older, this result is not unexpected.

\section{Determinants of shareholder approval}

Firms have the discretion to ask shareholders to approve the board appointment of representatives of the private purchasers. The entrenchment and monitoring hypotheses suggest that when internal control mechanisms are weak and agency problems are severe, firms are more likely to bypass shareholder approval. According to the approval irrelevance hypothesis, shareholder approval does not

Journal of Corporate Finance, Vol. 13, No. 4 (September 2007): pg. 485-510. DOI. This article is @ Elsevier and permission has been granted for this version to appear in e-Publications@Marquette. Elsevier does not grant permission for this article to be further copied/distributed or hosted elsewhere without the express permission from Elsevier. 
guarantee that the appointed directors will promote the interests of shareholders and the firm might decide to avoid approval only to reduce costs.

To investigate the possible motivations behind the decision to ask for shareholder approval, we estimate a probit regression in which the dependent variable is equal to one when the firm asks for shareholder approval of board appointments and is zero otherwise. The independent variables are the measures of internal and external monitoring quality, past performance, firm characteristics, and issue characteristics reported in Table 2.

The first two models of Table 3 reveal that when the chairman is one of the top managers of the firm (Insiderchair), the company is less likely to ask for shareholder approval. ${ }^{9}$ Other board characteristics such as board size and the percentage of insiders on the board do not have a significant relation with approval. The Insiderchair variable remains highly significant even after controlling for firm size (Lnassets) and issue size (Fraction_placed). Other variables that are significantly different between the approval/non-approval subsamples in the univariate tests such as institutional ownership, number of directors appointed, and stock exchange, fail to retain their significance after controlling for other variables. We control for state provisions that require shareholder approval to change the maximum number of directors following the issuance of shares with the indicator variable State_rule. We find that State_rule significantly affects the probability that a firm will ask for shareholder approval of board appointments. Past performance, measured as the abnormal $Q$ in the year prior to the private placement, is not significantly related to the decision to ask for shareholder approval. ${ }^{10}$

Models 10 and 11 include a modified version of our standardized measure of Jensen (1986) free cash flow, Freecash_assets1. Freecash_assets1 is equal to zero when free cash flows are negative and it is equal to Freecash_assets when free cash flows are positive. Since, as presented in Table 2, about half of our sample firms have negative cash flows, this modification allows a better estimation of the potential agency conflicts and entrenchment within our sample firms. If firms bypass shareholder approval because they need to accelerate the receipt of external funding, the coefficient of Freecash_assets1 should be positive. If free cash flow, however, measures managerial entrenchment while firms with greater entrenchment tend to bypass 
shareholder approval, the coefficient should be negative. Our result is consistent with the entrenchment and monitoring hypotheses. Even after controlling for the type of security issued (Common and Preferred), state provisions (State_rule), and the shareholder approval of the security issued privately (Secur_approval), the two entrenchment variables, Insiderchair and Freecash/assets1, are still significantly related to the firm's decision to ask shareholders to approve the appointment of directors in connection with the private placement. 11

We estimate the economic significance of each coefficient for model 11 , the most comprehensive, as the change in the probability that a firm will seek shareholder approval when the variable increases from the 25th to the 75th percentile (or from zero to one for indicator variables) while all other variables retain their median values. The probability of seeking shareholder approval decreases by $2.16 \%$ when Freecash/assets1 increases from the 25th to the 75th percentile. Insiderchair demonstrates a stronger economic significance. The probability of asking for shareholder approval for a firm in which one of the top managers is also the chairman is $16.8 \%$ lower compared to a firm in which the board chairman is an outsider. Among the control variables, State_rule is most economically significant. The probability of seeking shareholder approval for board appointments is $35.5 \%$ higher when the applicable state law requires shareholders to approve an increase in board size.

Overall, the results presented in Table 3 are consistent with the entrenchment and monitoring hypotheses. We find that firms in which the board chairman is a company manager and for which Jensen's (1986) free cash flow is higher, are more likely to circumvent shareholder approval. The test presented in Table 3 cannot distinguish between the entrenchment and monitoring hypotheses since both predict weak internal monitoring prior to private placements with board appointments without shareholder approval. The analysis reported in the following sections, however, allow us to further examine the relative validity of these two hypotheses.

\section{Monitoring quality of appointed directors}

In this section we directly test our three hypotheses by comparing the identities and activities of the directors appointed at the time of the private placement regardless of shareholder approval

Journal of Corporate Finance, Vol. 13, No. 4 (September 2007): pg. 485-510. DOI. This article is @ Elsevier and permission has been granted for this version to appear in e-Publications@Marquette. Elsevier does not grant permission for this article to be further copied/distributed or hosted elsewhere without the express permission from Elsevier. 
status. The entrenchment hypothesis differs from the approval irrelevance and monitoring hypotheses in its prediction regarding the monitoring provided by the appointed directors. The entrenchment hypothesis argues that firms with entrenched managers will tend to appoint directors who support managers' decisions and do not provide effective monitoring. To appoint such directors, management is likely to bypass shareholder approval. According to the approval irrelevance hypothesis, the quality of the newly appointed directors does not depend on the firm's decision to seek shareholder approval since managers are certain that shareholders, if asked, will automatically approve management's nominees regardless of their characteristics. Finally, the monitoring hypothesis predicts that firms that bypass shareholders' approval will increase the board's monitoring quality. This hypothesis contends that private investors demand immediate board representation to prevent managerial exploitation of corporate resources.

We measure the monitoring effectiveness of the appointed directors by determining how many appointed directors are independent, if they assume the board chairmanship, and their membership on board committees. As indicated by several studies, independent directors monitor managers more effectively and better represent shareholders' interests. Weisbach (1988) finds that the number of independent directors is positively related to the likelihood of removal of poorly performing CEOs, while Byrd and Hickman (1992) show that tender offers are characterized by higher bidder returns when the board has a majority of independent directors. Brickley et al. (1994) find that the market reacts positively when firms with a board dominated by outsiders adopt a poison pill. Although a few firms in our sample appoint new managers or managers of their own subsidiaries to their board at the time of the private placement, the great majority of these directors are either gray or independent. Gray directors include relatives of top managers and outsiders with disclosed outside business dealings with the company. ${ }^{12}$ We measure both the number of independent directors appointed (Independent), and the ratio of the number of independent appointed directors to the size of the board after the placement (Fraction_ind). This latter measure allows us to assess the aggregate decisional influence that the new independent directors might have on the board.

Journal of Corporate Finance, Vol. 13, No. 4 (September 2007): pg. 485-510. DOI. This article is (C Elsevier and permission has been granted for this version to appear in e-Publications@Marquette. Elsevier does not grant permission for this article to be further copied/distributed or hosted elsewhere without the express permission from Elsevier. 
Since entrenched boards are less likely to delegate power to new outside constituents, the appointment of one of the new directors as chairman of the board, particularly if the director is independent, is symptomatic of less entrenchment Jensen (1993) argues that when the CEO rather than an independent director holds the board chairmanship, the board ceases being an effective internal monitoring device. Goyal and Park (2002) find that the sensitivity of CEO turnover to firm performance is significantly lower in firms where the same individual holds both the CEO and chairman position. In our analysis we create an independent variable equal to one when one of the appointed directors is also appointed chairman of the board (Chair), and an independent variable equal to one when one of the independent appointed directors is also appointed chairman of the board (Inc_chair).

Membership by the newly appointed directors on board committees is another measure of corporate governance quality. Membership on board committees can be viewed as a proxy for monitoring intensity since board monitoring is a function not only of the composition of the board as a whole, but also of the structure and composition of the board committees. Kesner (1988) observes that most important board decisions originate at the committee level. Klein (1998) finds that overall board composition is unrelated to firm performance, but that the structure of the compensation and audit committees does impact performance. To measure the role that appointed directors play on board committees, we measure the fraction of all committee seats, audit committee seats, and compensation committee seats that are filled by the appointed directors.

Table 4 provides a set of descriptive univariate statistics for the appointed directors. Firms that bypass shareholder approval appoint on average 1.14 independent directors while firms seeking shareholder approval appoint an average of 1.87 independent directors. The difference in these means is significant at the $1 \%$ level. The ratio of the number of independent appointed directors to the board size averages 0.15 for the subsample of firms that bypass shareholder approval, but 0.24 for the subsample of firms that seek it. This difference is also significant at the $1 \%$ level. We find that firms asking for shareholder approval are more likely to appoint one of the new directors as board chairman, particularly when we exclude gray

Journal of Corporate Finance, Vol. 13, No. 4 (September 2007): pg. 485-510. DOI. This article is @ Elsevier and permission has been granted for this version to appear in e-Publications@Marquette. Elsevier does not grant permission for this article to be further copied/distributed or hosted elsewhere without the express permission from Elsevier. 
directors. Only $5 \%$ of the firms in the "no-approval" subsample appoint a new independent director as chairman while $17 \%$ of the firms in the "approval" subsample appoint a new independent director as chairman. This difference is statistically significant at the $5 \%$ level. The difference in the proportion of total committee, audit committee, and compensation committee seats filled by appointed directors between the two subsamples is not significant

As shown in Section 5, firms with an insider as chairman and firms with larger amounts of free cash flow are more likely to bypass shareholder approval of board appointments at the time of the private placement To verify if the firm's decision to bypass shareholder approval is related to the appointment of passive directors even after controlling for other measures of managerial entrenchment, we independently regress Fraction_ind and Inc_chair on the approval indicator variable and several proxies for the quality of corporate governance. As shown in Tables 1 and 2, firms that ask for shareholder approval tend to appoint a larger number of private investor representatives to the board. Since this factor might drive the significant differences we observe in Table 4, we also control for the number of directors appointed.

Panel A of Table 5 presents the results of the regression in which the dependent variable is the ratio of the number of appointed independent directors to the total number of directors. Since several firms fail to appoint any independent directors, the dependent variable of the regression reported in Panel $A$ is left-censored at zero. We estimate a Tobit regression to account for the censoring of the dependent variable. The approval indicator variable is positive and significant even after controlling for firm size (Lnassets), and governance variables. When we control for the number of directors appointed (column 4 and 5) the approval indicator variable remains statistically significant. The size of the board before the placement (Board_size) is significantly negative at the $1 \%$ level. This variable is significant because board size prior to the private placement is positively correlated with board size after the placement, which is the denominator of the dependent variable. Past performance, measured as the abnormal $Q$ in the year prior to the placement, is negative and significantly related to the fraction of appointed independent directors. This result is consistent with Hermalin and Weisbach (1998).

Journal of Corporate Finance, Vol. 13, No. 4 (September 2007): pg. 485-510. DOI. This article is (C Elsevier and permission has been granted for this version to appear in e-Publications@Marquette. Elsevier does not grant permission for this article to be further copied/distributed or hosted elsewhere without the express permission from Elsevier. 
NOT THE PUBLISHED VERSION; this is the author's final, peer-reviewed manuscript. The published version may be accessed by following the link in the citation at the bottom of the page.

Panel B of Table 5 presents the results of a probit regression in which the dependent variable is an indicator variable equal to one when one of the appointed independent directors is also appointed chairman of the board. The approval indicator variable is significantly positive at the $5 \%$ level even after controlling for firm size (Lnassets), governance variables, and the number of directors appointed.

Overall, the results reported in Tables 4 and 5 support the entrenchment hypothesis. Firms that circumvent shareholder approval are more likely to appoint directors supportive of management and unlikely to offer meaningful monitoring. Our result that firms with entrenched management are more likely to bypass shareholders to appoint fewer independent directors is also consistent with Shivdasani and Yermack (1999).

\section{Market reaction at the time of the announcement}

Our three hypotheses predict different market reactions to the announcement of board appointments in connection with a private placement. If the avoidance of shareholder approval is a manifestation of agency problems, then the announcement of board appointments conditional on shareholder approval should signal less entrenchment. Consequently, such announcements should be received positively in the marketplace. Alternatively, if voting by shareholders is irrelevant, shareholder approval should have no effect on stock market returns surrounding the announcement of such appointments. Finally, if shareholders are bypassed to allow the immediate appointment of new monitors to the board, then the market should not react more positively to the announcement of board appointments conditional of shareholder approval.

\subsection{Announcement period returns}

To ensure consistency in the information content of the announcements, we eliminate from our sample ten firms that announce the private placement and director appointments on different days. We calculate abnormal returns around the announcement date by estimating the market model over the day-300 to day-46 window relative to the announcement date. The market return is proxied by the CRSP equally-weighted market index. Table 6 presents the cumulative average abnormal returns (CAARs) for a two-

Journal of Corporate Finance, Vol. 13, No. 4 (September 2007): pg. 485-510. DOI. This article is @ Elsevier and permission has been granted for this version to appear in e-Publications@Marquette. Elsevier does not grant permission for this article to be further copied/distributed or hosted elsewhere without the express permission from Elsevier. 
day period beginning at the announcement date $(0,1)$, a three-day period centered around the announcement date $(-1,1)$, and a five-day period spanning days -2 through day +2 . Since Factiva reports announcements with the date and time at which they were originally released, we believe that the $(0,1)$ interval provides results with the least potential to be affected by confounding events.

Panel A of Table 6 presents the CAARs for all the firms announcing board appointments in connection with a private offering. Consistent with the event studies on private placements by Wruck (1989) and Hertzel and Smith (1993), the CAARs are positive and statistically significant for all three examination windows. The magnitude of these CAARs, however, is larger than those of previous studies. The difference might be attributable to different samples since we examine placements of common stock as well as hybrid securities. Additionally, all of our sample offerings are associated with board appointments, and none of the securities are placed with the issuing firm's managers.

The CAARs for the non-approval and approval subsamples reported in panels $B$ and $C$ provide preliminary evidence that firms announcing board appointments conditional on shareholder approval are associated with larger abnormal announcement returns. For the $(0,1)$ window, the cumulative abnormal return for the approval subsample is $8.27 \%$ while that for the non-approval subsample is $4.96 \%$.

To isolate the effect of circumvention of shareholder approval on market returns from the other information contained in the security issuance announcement, we control for a set of variables associated with capital raising by estimating a series of OLS regressions with the cumulative abnormal returns for the $(0,1)$ window as the dependent variable. We provide the results of these regressions in Table 7 . When the approval-of-directors indicator variable (Approval) is the only independent variable, its coefficient is positive and large in magnitude, but not significant. When the security approval indicator variable (Secur_approval) is introduced into the model, the approval of directors becomes statistically significant at the $10 \%$ level. The security approval indicator is negative and statistically significant. As discussed in Section 3, in many cases firms ask for shareholder approval of the security issuance when the listing exchange requires them to do so. Moreover, shareholder approval of the security

Journal of Corporate Finance, Vol. 13, No. 4 (September 2007): pg. 485-510. DOI. This article is @ Elsevier and permission has been granted for this version to appear in e-Publications@Marquette. Elsevier does not grant permission for this article to be further copied/distributed or hosted elsewhere without the express permission from Elsevier. 
issuance is sometimes associated with amendments in the charter that can be deleterious to shareholders. For example, firms that ask shareholders to approve the issuance of preferred convertible shares might also amend the charter to include a blank check preferred stock provision. This provision can be used as a takeover defense since it allows the implementation of poison pills without shareholder approval, and therefore it might be negatively received by the market. The introduction of anti-takeover amendments explains, at least partially, the sign of the coefficient for Secur_approval. ${ }^{13}$

The announcement of a private placement associated with board appointments also provides investors with information about the identity of the new directors and a possible change in board size. To control for the potential effect of this additional information on announcement returns, in column (3) of Table 7 we include as regressors the fraction of newly appointed independent directors (Fraction_ind) and the change in board size (Board_size_change). These two variables are not significant; however, the director approval indicator variable remains significant at the $5 \%$ level. The director approval indicator variable remains significant even after the introduction of firms size, the level of free cash flow and several control variables associated with the private offering such as the fraction of shares placed, the type of security placed, the change in the ownership by officers, directors, and outside blockholders due to the private placement, whether the private purchaser is a corporation, and state provisions. In the reported regressions we consider the fraction of stock owned by firms managed or owned by directors as part of directors' stock ownership. When we consider that fraction as owned by outside blockholders, our results do not significantly change.

\subsection{Discounted adjusted abnormal returns}

Wruck (1989) observes that private equity is usually sold at a discount to compensate the purchaser for positively contributing to firm value or for maintaining managerial entrenchment. Consequently, the abnormal return observed around the announcement of a private placement must be adjusted for this component representing compensation to the private purchaser. To measure the abnormal return due only to the information revealed to the market, we use the model developed by Bradley and Wakeman (1983) and applied by Wruck (1989) and Hertzel and Smith (1993) to calculate the discount-

Journal of Corporate Finance, Vol. 13, No. 4 (September 2007): pg. 485-510. DOI. This article is @ Elsevier and permission has been granted for this version to appear in e-Publications@Marquette. Elsevier does not grant permission for this article to be further copied/distributed or hosted elsewhere without the express permission from Elsevier. 
adjusted abnormal returns (DAAR). Since the Bradley and Wakeman model applies only to common stock placements, we calculate DAAR for only the 67 firms of our sample that place common stock to private investors and announce the private offering and appointment of directors on the same day. ${ }^{14}$

As shown in Panel A of Table 8, the discount-adjusted abnormal returns for our subsample of common stock private placements is large $(11.60 \%)$ and statistically significant. The DAAR for the six firms that seek shareholder approval of board appointments is very large $(38.8 \%)$ and significantly higher than the DAAR of the firms that bypass shareholder approval. We further analyze the effect of shareholder approval of directorships on discount-adjusted abnormal returns by estimating an OLS regression with DAAR as the dependent variable. Panel B of Table 8 contains the results. The director approval variable is significantly positive at the $5 \%$ level even after the introduction of the control variables used in Table 7.

Overall, this event study analysis shows that the market strongly rewards firms that submit their director candidates for shareholder approval. This result is consistent with the entrenchment hypothesis. The market reacts positively to the announcement of shareholder approval because it infers a lower level of entrenchment and consequently revises its estimations of the firm's future cash flows.

\section{Does shareholder approval impact performance?}

The entrenchment hypothesis predicts that firms seeking shareholder approval perform better than firms bypassing shareholder approval since the firm's decision to ask for shareholder approval is a manifestation of better corporate governance. Alternatively, the approval irrelevance hypothesis predicts that the approval of directorships does not affect the firm's future performance. Finally, the monitoring hypothesis predicts that companies bypass shareholder approval to grant immediate board representation to private investors who wish to monitor the company. Therefore, firms that bypass shareholder approval, ceteris paribus, might improve performance relative to those firms that seek shareholder approval. We examine both the firms' operating and stock performance following private placements associated with board appointments to determine what

Journal of Corporate Finance, Vol. 13, No. 4 (September 2007): pg. 485-510. DOI. This article is (C Elsevier and permission has been granted for this version to appear in e-Publications@Marquette. Elsevier does not grant permission for this article to be further copied/distributed or hosted elsewhere without the express permission from Elsevier. 
impact the level of managerial entrenchment implied by the approval/non-approval of these appointments has on the firm's performance.

\subsection{Operating performance}

We estimate abnormal operating performance by using the Lie (2001) modification of the Barber and Lyon (1996) method as applied by Grullon and Michaely (2004). The abnormal operating performance is calculated as the operating performance of the sample firm minus the operating performance of the matching firm. Our measure of operating performance is operating income before depreciation scaled by the average of the beginning-period and ending-period book value of total assets (ROA). We select matching firms that have the same industry classification as the sample firms and are comparable in their level of performance during the year preceding the private issue (year1 ), their change in performance from year-2 to year-1, and their market-to-book ratio for year-1.

The results from this analysis are not tabulated, but available upon request from the authors. Our aggregate sample of firms that appoint directors in connection with a private offering significantly underperform in the fiscal year including the private issue date. This result is consistent with the evidence offered by Hertzel et al. (2002). The abnormal operating performance for the approval subsample is significantly positive in all three years following the private offering. Most importantly, when we compare the approval/non-approval subsamples we find that the difference of the medians in year one, the difference of the means in year two, and both the difference of the means and medians in year three are positive and significant. This result reveals that firms that seek shareholder approval of board appointments at the time of the private placement perform significantly better in the three years following the offering than firms that bypass shareholder approval. The significant difference in performance between the two approval subsamples is consistent with the entrenchment and monitoring hypothesis.

\subsection{Stock performance}

\subsubsection{Buy-and-hold abnormal returns}

We calculate BHARs for the first 3 years following the announcement of private placements by matching each firm in our

Journal of Corporate Finance, Vol. 13, No. 4 (September 2007): pg. 485-510. DOI. This article is (C Elsevier and permission has been granted for this version to appear in e-Publications@Marquette. Elsevier does not grant permission for this article to be further copied/distributed or hosted elsewhere without the express permission from Elsevier. 
sample to a matching firm by size and book-to-market ratio as suggested by Barber and Lyon (1997). Consistent with Hertzel et al. (2002), the BHARs following private placements are negative and large in magnitude. The difference in the BHARs between the approval and non-approval sub-samples, however, is statistically insignificant.

When we consider the BHARs at the end of the first, second, and third year following the private placement, we find that the stocks of firms asking for shareholder approval of directorships significantly outperform those of firms that bypass shareholder approval. The mean of the difference between the one-year BHARs of the approval/nonapproval subsamples as well as the corresponding difference for the three-year BHARs are statistically significant.

\subsubsection{Calendar-time abnormal returns}

As noted by Fama (1998) and Mitchell and Stafford (2000), the buy-and-hold method does not account for cross-sectional dependence in returns. We address this issue by also estimating three-year abnormal returns using the calendar-time approach. For each calendar month in our sample period, we form a portfolio of the sample firms that have announced a private placement during the last 36 months. We exclude those months with less than ten firms in the portfolio. We then regress the monthly portfolio excess returns on the three Fama and French (1993) factors.

The calendar-time regression indicates that the three-year abnormal return is $-10.58 \%$. The three-year abnormal return for the non-approval sample and approval sample are $-17.65 \%$ and $+27.98 \%$, respectively. To investigate if the difference of the portfolio abnormal returns for the two approval subsamples is significant, we regress the difference in the monthly portfolio excess returns for the two subsamples on the three Fama and French (1993) factors. The difference of the three-year abnormal returns for the two subsamples is large, (73.36\%), but insignificant. ${ }^{15}$

\subsection{Long-term performance and announcement returns}

Overall, the long-term performance results are consistent with the entrenchment hypothesis. The difference in the abnormal operating performance between the two approval subsamples is significant in the 3 years following the private placement. Even though

Journal of Corporate Finance, Vol. 13, No. 4 (September 2007): pg. 485-510. DOI. This article is @ Elsevier and permission has been granted for this version to appear in e-Publications@Marquette. Elsevier does not grant permission for this article to be further copied/distributed or hosted elsewhere without the express permission from Elsevier. 
the buy-and-hold stock returns are partially suggestive of a difference in the long-term stock performance between the approval/nonapproval subsamples, when we control for cross-sectional dependence in returns with the calendar time portfolio method, the statistical significance vanishes. Nevertheless, the lack of statistical significance in the difference of long-term stock performance between the two subsamples does not contradict the entrenchment hypothesis. In an efficient market, the increase in share price should occur when a firm announces the decision to seek shareholder approval and not gradually in the following years.

\section{Conclusions}

This paper investigates the causes and consequences of the appointment of directors to corporate boards without shareholder approval in the context of private placements. We show that firms with greater managerial entrenchment are more likely to bypass shareholder approval for their appointments. Such firms are also less likely to appoint independent directors or to elect one of the appointed directors as chairman of the board. Moreover, the stock market reacts more positively to the announcement of the private offering when the firm submits the board candidates for shareholder approval. Finally, firms that bypass shareholder approval underperform compared to firms that obtain shareholder approval.

Overall, the results of this study are consistent with recent findings by Wu (2004) and Barclay et al. (2007-this issue) that challenge the conventional view of private placements as enhancing the quality of monitoring. Although there are multiple reasons for the private placement of securities, our findings indicate that entrenchment has a stronger influence on the private placement process than previously believed.

Our results are also consistent with the view that entrenched managers are likely to nominate directors that protect managers' positions and interests. Since such directors do not represent the interests of outside shareholders, entrenched managers will adopt strategies that allow them to appoint "friendly" directors without asking for shareholder approval.

The current process for soliciting shareholder approval of board appointments surrounding private placements is not fully consistent with effective corporate governance. The various stratagems that

Journal of Corporate Finance, Vol. 13, No. 4 (September 2007): pg. 485-510. DOI. This article is (C Elsevier and permission has been granted for this version to appear in e-Publications@Marquette. Elsevier does not grant permission for this article to be further copied/distributed or hosted elsewhere without the express permission from Elsevier. 
managers can adopt to avoid shareholder approval neutralize the monitoring provided by shareholder voting. Our findings align with the observations of Bebchuck (2005) who argues that "shareholders' existing power to replace directors is insufficient to secure the adoption of value-increasing governance arrangements that management disfavors." Indeed, those firms that could benefit the most from the monitoring provided by shareholder approval are those most likely to avoid it.

\section{Endnotes}

- a Department of Finance, 312 Straz Hall. Marquette University. Milwaukee. WI 53201-1881, United States

- b Department of Finance. 404 Cornell Hall, University of Missouri-Columbia, Columbia, MO 65211-2600, United States

- $\diamond$ We wish to thank Royce Barondes, Paul Brockman, Mark Frigo, Clifford Holderness, John Howe, Tim Loughran, Michael McCracken, Hamid Mehran, Kenneth Scott, Tina Yang, an anonymous referee, and seminar participants at the University of Missouri-Columbia, the 2005 European meeting of the FMA, the 2005 FMA annual meeting, and the Journal of Corporate Finance Special Issue Conference on "Private Equity, Leveraged Buyouts, and Corporate Governance" for helpful comments and suggestions. We also wish to thank Qi (Carol) Wang for her research assistance. While at University of Missouri, Arena received support from the Alan C. Greenberg Summer Research Fellowship and the Ponder Scholarship Fund.

- *Corresponding author. Tel.: +1 414-288-3369.

- E-mail addresses: matteo.arena@mu.edu (M.P. Arena), ferriss@missouri.edu (S.P. Ferris).

- 1 Tel.: +1 573-882-9905.

- $\quad 2$ See for example "Stock Activism's Latest Weapon" By Mark Maremont and Erin White, Wall Street Journal, April 4, 2006.

- ${ }^{3}$ If shareholders are not satisfied by the management's slate they can propose their own candidates. Excluding contests related to M\&A activity, Bebchuk (2003) reports that there were 77 contested director proxies between 1996 and 2002.

Journal of Corporate Finance, Vol. 13, No. 4 (September 2007): pg. 485-510. DOI. This article is @ Elsevier and permission has been granted for this version to appear in e-Publications@Marquette. Elsevier does not grant permission for this article to be further copied/distributed or hosted elsewhere without the express permission from Elsevier. 
Therefore it is plausible that managers expect the probability of shareholders rejecting management slate to be greater than zero.

- ${ }^{4}$ One might argue that firms bypass shareholder approval when they are in financial distress and have an immediate need for funds. Immediacy concerns, however, do not require managers to circumvent the shareholder approval process regarding the appointment of directors. Firms in financial distress can execute an immediate private placement of securities and wait until the annual meeting to appoint the new directors.

- ${ }^{5}$ Convertible notes require shareholder approval at the time of the conversion if the corporation's authorized common shares are less than the shares resulting from the conversion.

- ${ }^{6}$ See Rule 312.03 of the NYSE Listed Company Manual, Nasdaq Marketplace Rule 4350(i), and Section 713 of the AMEX Company Guide.

- 7 See MBCA sec. 10.20; DGCL sec. 109. Only a few states, including California, Massachusetts, North Carolina, and Virginia, require shareholder approval to change the maximum number of directors following share issuance. We control for such a provision in our multivariate analysis.

- ${ }^{8}$ Bajaj et al. (2000) report that $22 \%$ of all securities fraud class action law suits during the 1991-1999 period are claims of breaches of fiduciary responsibility. The Stanford University Security Class Action Clearinghouse serves as an authoritative source of data regarding such litigation. It reports for 2005 that $93 \%$ of the cases filed in 2005 were due to Section $10 b-5$ (untrue statements and fraud), Section 11 (false registration statements) or Section 12(2) (false statements in prospectuses or other communications). Such claims are often then linked with breaches of fiduciary responsibilities by directors or corporate managers.

- ${ }^{9}$ We obtain similar results when we substitute this variable with Ceochair, an indicator variable equal to one when the CEO is also the chairman of the board. 
- 10 When we substitute abnormal Q with an industry-normed ROA, we obtain similar results.

- ${ }^{11}$ In unreported regressions we also estimate the effect of a CEO tenure variable, and of an indicator equal to one when the CEO is the founder of the firm. The coefficients of these variables are not significant.

- $\quad 12$ The private investment is not considered a business dealing by itself. Private investors who are appointed to the board are classified as independent if they do not have other business connections with the issuer.

- 13 The negative coefficient of Secur_approval does not mean that the reaction of the announcement of a private placement that requires shareholder approval is negative, but only that is less positive since the unconditional abnormal return is larger in magnitude than the Secur_approval coefficient.

- $\quad 14$ Some of these firms also place hybrid securities additionally to common shares. We control for this in the OLS regressions 5 and 6 reported in Panel B of Table 8.

- ${ }^{15}$ When we calculate calendar-time abnormal returns using the correction proposed by Shumway (1997) and Shumway and Warther (1999) for companies which delist, the results are not significantly different.

\section{References}

Aghion, P., Bolton, P., 1992. An incomplete contracts approach to financial contracting. Review of Economic Studies 59, 473-494.

Bajaj, M., Mazumdar, S.C., Sarin, A., 2000. Securities Class Action Settlements: An Empirical Analysis. Working Paper.

Balachandran, S.V., Joos, P.R., Weber, J., 2004. Do voting rights matter: evidence from the adoption of equity-based compensation plans. Working Paper, MIT Sloan School of Management.

Barber, B.M., Lyon, J.D., 1996. Detecting abnormal operating performance: the empirical power and specification of test statistics. Journal of Financial Economics 41, 359-399.

Barber, B.M., Lyon, J.D., 1997. Detecting long-run abnormal stock returns: the empirical power and specification of test statistics. Journal of Financial Economics 43, 341-372.

Journal of Corporate Finance, Vol. 13, No. 4 (September 2007): pg. 485-510. DOI. This article is @ Elsevier and permission has been granted for this version to appear in e-Publications@Marquette. Elsevier does not grant permission for this article to be further copied/distributed or hosted elsewhere without the express permission from Elsevier. 
NOT THE PUBLISHED VERSION; this is the author's final, peer-reviewed manuscript. The published version may be accessed by following the link in the citation at the bottom of the page.

Barclay, M.J., Holderness, C.G., Sheehan, D.P., 2007. Private placements and managerial entrenchment. Journal of Corporate Finance 13, 461-484 (this issue), doi:10.1016/j.jcorpfin.2007.04.009.

Bebchuck, L.A., 2003. The case for shareholder access to the ballot. Business Lawyer 59, 43-66.

Bebchuck, L.A., 2005. The case for increasing shareholder power. Harvard Law Review 118, 836-843.

Berle, A.A., Means, G.C., 1932. The Modern Corporation and Private Property. MacMillan, New York.

Bethel, J.E., Gillan, S.L., 2002. The impact of the institutional and regulatory environment on shareholder voting. Financial Management 31, 29-54.

Boehmer, E., Musumeci, J., Poulsen, A.B., 1991. Event study methodology under conditions of event-induced variance. Journal of Financial Economics 30, 253-272.

Bradley, M., Wakeman, L.M., 1983. The wealth effects of targeted share repurchases. Journal of Financial Economics 11, 301-328.

Brickley, J.A., Coles, J.L., Terry, R.L., 1994. Outside directors and the adoption of poison pills. Journal of Financial Economics 35, 371-390.

Brown, S.J., Warner, J.B., 1985. Using daily stock returns: the case of event studies. Journal of Financial Economics 14, 3-31.

Burch, T.R., Morgan, A.G., Wolf, J.G., 2004. Is acquiring-firm shareholder approval in stock-for-stock mergers perfunctory? Financial Management 33, 45-69.

Byrd, J.W., Hickman, K.A., 1992. Do outside directors monitor managers? Evidence from tender offer bids. Journal of Financial Economics 32, 195-221.

DeAngelo, H., DeAngelo, L., 1989. Proxy contests and the governance of publicly held corporations. Journal of Financial Economics 23, 29-60.

Demb, A., Neubauer, F., 1992. The corporate board. Oxford University Press, Oxford.

Easterbrook, F.H., Fischel, D.R., 1983. Voting in corporate law. Journal of Law and Economics 26, 395-428.

Fama, E.F., 1998. Market efficiency, long-term returns, and behavioral finance. Journal of Financial Economics 49, 283-306.

Fama, E.F., French, K.R., 1993. Common risk factors in the returns on stocks and bonds. Journal of Financial Economics 33, 3-56.

Fama, E.F., French, K.R., 2002. Testing trade-off and pecking order predictions about dividends and debt. Review of Financial Studies 15, 1-33.

Fama, E.F., Jensen, M.C., 1983. Separation of ownership and control. Journal of Law and Economics 26, 301-326.

Goyal, V.K., Park, C.W., 2002. Board leadership structure and CEO turnover. Journal of Corporate Finance 8, 49-66.

Journal of Corporate Finance, Vol. 13, No. 4 (September 2007): pg. 485-510. DOI. This article is @ Elsevier and permission has been granted for this version to appear in e-Publications@Marquette. Elsevier does not grant permission for this article to be further copied/distributed or hosted elsewhere without the express permission from Elsevier. 
NOT THE PUBLISHED VERSION; this is the author's final, peer-reviewed manuscript. The published version may be

accessed by following the link in the citation at the bottom of the page.

Grossman, S.J., Hart, O.D., 1986. The costs and benefits of ownership: a theory of vertical and lateral integration. Journal of Political Economy 94, 691-719.

Grullon, G., Michaely, R., 2004. The information content of share repurchase programs. Journal of Finance 59, 651-680.

Hart, O.D., Moore, J., 1988. Incomplete contracts and renogotiation. Econometrica 56, 755-786.

Hart, O.D., Moore, J., 1990. Property rights and the nature of the firm. Journal of Political Economy 98, 1119-1158.

Hermalin, B.E., Weisbach, M.S., 1998. Endogenously chosen boards of directors and their monitoring of the CEO. American Economic Review 88, 96-118.

Hertzel, M., Lemmon, M., Linck, J.S., Rees, L., 2002. Long-run performance following private placements of equity. Journal of Finance 57, 25952617.

Hertzel, M., Smith, R.L., 1993. Market discounts and shareholder gains for placing equity privately. Journal of Finance 48, 459-486.

Jensen, M.C., 1986. Agency costs of free cash flow, corporate finance, and takeovers. American Economic Review 76, 323-329.

Jensen, M.C., 1993. Presidential address: the modern industrial revolution, exit, and the failure of internal control systems. Journal of Finance 48, 831-880.

Kaplan, S.S., Stromberg, P., 2003. Financial contracting meets the real world: an empirical analysis of venture capital contracts. Review of Economic Studies 70, 281-315.

Kesner, I.F, 1988. Directors characteristics and committee membership: an investigation of type, occupation, tenure and gender. Academy of Management Journal 31, 66-84.

Klein, A., 1998. Firm performance and board committee structure. Journal of Law and Economics 41, 275-303.

Lehn, K., Poulsen, A., 1989. Free cash flow and stockholder gains in going private transactions. Journal of Finance 44, 771-788.

Lie, E., 2001. Detecting abnormal operating performance: revisited. Financial Management 30, 77-91.

Lorsch, J.W., 1989. Pawns or potentates: the reality of America's corporate boards. Harvard Business School Press, Boston.

McIntosh, C.S., Dorfman, J.H., 1992. Qualitative forecast evaluation: a test for information value. American Journal of Agricultural Economics 74, 209-214.

Mitchell, M.L., Stafford, E., 2000. Managerial decisions and long-term stock price performance. Journal of Business 73, 289-329.

Palia, D., 2001. The endogeneity of managerial compensation in firm valuation: a solution. Review of Financial Studies 14, 735-764.

Journal of Corporate Finance, Vol. 13, No. 4 (September 2007): pg. 485-510. DOI. This article is (C) Elsevier and permission has been granted for this version to appear in e-Publications@Marquette. Elsevier does not grant permission for this article to be further copied/distributed or hosted elsewhere without the express permission from Elsevier. 
NOT THE PUBLISHED VERSION; this is the author's final, peer-reviewed manuscript. The published version may be accessed by following the link in the citation at the bottom of the page.

Patell, J., 1976. Corporate forecasts of earnings per share and stock price behavior: empirical tests. Journal of Accounting Research 14, 246-276.

Shivdasani, A., Yermack, D., 1999. CEO involvement in the selection of new board members: an empirical analysis. Journal of Finance 54, 18291853.

Shumway, T., 1997. The delisting bias in CRSP data. Journal of Finance 52, 327-340.

Shumway, T., Warther, V.A., 1999. The delisting bias in CRSP's Nasdaq data and its implications for the size effect. Journal of Finance 54, 23612379.

Weisbach, M.S., 1988. Outside directors and CEO turnover. Journal of Financial Economics 20, 431-460.

Wruck, K.H., 1989. Equity ownership concentration and firm value: evidence from private equity financings. Journal of Financial Economics 23, 329.

Wu, Y., 2004. The choice of equity-selling mechanisms. Journal of Financial Economics 74, 93-119.

Journal of Corporate Finance, Vol. 13, No. 4 (September 2007): pg. 485-510. DOI. This article is @ Elsevier and permission has been granted for this version to appear in e-Publications@Marquette. Elsevier does not grant permission for this article to be further copied/distributed or hosted elsewhere without the express permission from Elsevier. 
NOT THE PUBLISHED VERSION; this is the author's final, peer-reviewed manuscript. The published version may be accessed by following the link in the citation at the bottom of the page.

\section{Appendix A. Description of variables}

The variables are reported in alphabetical order

\begin{tabular}{|c|c|}
\hline Variable & Definition \\
\hline Age & $\begin{array}{l}\text { Number of years from the CRSP listing date to the } \\
\text { offering date }\end{array}$ \\
\hline Alliance & $\begin{array}{l}\text { Indicator variable equal to one when the private investor } \\
\text { is a corporation }\end{array}$ \\
\hline Approval & $\begin{array}{l}\text { Indicator variable equal to one when the firm appoints } \\
\text { directors with shareholder approval }\end{array}$ \\
\hline Assets & $\begin{array}{l}\text { Total assets of the firm expressed in millions of dollars } \\
\text { calculated at the end of the fiscal year preceding the } \\
\text { private placement }\end{array}$ \\
\hline Audit & $\begin{array}{l}\text { Proportion of audit committee seats filled by the } \\
\text { directors appointed in connection with the private } \\
\text { placement }\end{array}$ \\
\hline Board_size & Size of the board before the private placement \\
\hline Board_size_change & $\begin{array}{l}\text { Difference between board size after the placement and } \\
\text { board size before the placement divided by the board } \\
\text { size before the placement }\end{array}$ \\
\hline Ceochair & $\begin{array}{l}\text { Indicator variable that is equal to one when the chief } \\
\text { executive officer of the firm is also the chairman of the } \\
\text { board before the private placement }\end{array}$ \\
\hline Chair & $\begin{array}{l}\text { Indicator variable equal to one when one of the directors } \\
\text { appointed in connection with the private placement is } \\
\text { also appointed chairman of the board }\end{array}$ \\
\hline Committee & $\begin{array}{l}\text { Proportion of committee seats filled by the directors } \\
\text { appointed in connection with the private placement }\end{array}$ \\
\hline Common & $\begin{array}{l}\text { Indicator variable equal to one when the company issues } \\
\text { common stock }\end{array}$ \\
\hline Compensation & $\begin{array}{l}\text { Proportion of compensation committee seats filled by the } \\
\text { directors appointed in connection with the private } \\
\text { placement }\end{array}$ \\
\hline Delta_block_own & $\begin{array}{l}\text { Difference of outside blockholder stock ownership before } \\
\text { and after the private placement }\end{array}$ \\
\hline Delta_offdir_own & $\begin{array}{l}\text { Difference of directors' and officers' stock ownership } \\
\text { before and after the private placement }\end{array}$ \\
\hline
\end{tabular}

Journal of Corporate Finance, Vol. 13, No. 4 (September 2007): pg. 485-510. DOI. This article is (C Elsevier and permission has been granted for this version to appear in e-Publications@Marquette. Elsevier does not grant permission for this article to be further copied/distributed or hosted elsewhere without the express permission from Elsevier. 
NOT THE PUBLISHED VERSION; this is the author's final, peer-reviewed manuscript. The published version may be accessed by following the link in the citation at the bottom of the page.

\begin{tabular}{|c|c|}
\hline Variable & Definition \\
\hline Dir_appointed & $\begin{array}{l}\text { Number of directors appointed at the time of the private } \\
\text { placement }\end{array}$ \\
\hline Founder & $\begin{array}{l}\text { Indicator variable that is equal to one when the CEO is } \\
\text { also one of the founders of the firm }\end{array}$ \\
\hline Fraction_ind & $\begin{array}{l}\text { Number of independent directors appointed divided by } \\
\text { the board size after the placement }\end{array}$ \\
\hline Fraction_placed & $\begin{array}{l}\text { Portion of common stock of the firm distributed through } \\
\text { the private placement (after conversion of preferred } \\
\text { shares, convertible notes, and warrants) }\end{array}$ \\
\hline Freecash/assets & $\begin{array}{l}\text { Operating income before depreciation, minus income } \\
\text { taxes corrected for the annual change in deferred taxes, } \\
\text { minus interest expense on debt, minus dividends on } \\
\text { preferred stock and common stock, all divided by the } \\
\text { value of total assets }\end{array}$ \\
\hline Freecash/assets1 & $\begin{array}{l}\text { Equal to Freecash/assets if Freecash/assets }>0 \text { and } \\
\text { equal to } 0 \text { if Freecash/assets } \leq 0\end{array}$ \\
\hline Ind_chair & $\begin{array}{l}\text { Indicator variable equal to one when one of the } \\
\text { independent directors appointed in connection with the } \\
\text { private placement is also appointed chairman of the } \\
\text { board }\end{array}$ \\
\hline Independent & $\begin{array}{l}\text { Number of independent directors appointed in } \\
\text { connection with the private placement }\end{array}$ \\
\hline Insider_own & $\begin{array}{l}\text { Share ownership of officers and directors before the } \\
\text { private placement }\end{array}$ \\
\hline Insiderchair & $\begin{array}{l}\text { Indicator variable that is equal to one when one of the } \\
\text { top managers of the firm is also the chairman of the } \\
\text { board before the private placement }\end{array}$ \\
\hline Insiders & $\begin{array}{l}\text { Number of insiders on the board divided by board size } \\
\text { before the placement }\end{array}$ \\
\hline Inst_own & $\begin{array}{l}\text { Institutional share ownership before the private } \\
\text { placement }\end{array}$ \\
\hline Leverage & $\begin{array}{l}\text { Total debt divided by total assets calculated at the end } \\
\text { of the fiscal year preceding the private placement }\end{array}$ \\
\hline Lnassets & Natural logarithm of Assets \\
\hline Marketcap & $\begin{array}{l}\text { Market capitalization of the firm on the day of the } \\
\text { announcement of the private placement expressed in } \\
\text { millions of dollars }\end{array}$ \\
\hline
\end{tabular}

Journal of Corporate Finance, Vol. 13, No. 4 (September 2007): pg. 485-510. DOI. This article is (C Elsevier and permission has been granted for this version to appear in e-Publications@Marquette. Elsevier does not grant permission for this article to be further copied/distributed or hosted elsewhere without the express permission from Elsevier. 
NOT THE PUBLISHED VERSION; this is the author's final, peer-reviewed manuscript. The published version may be accessed by following the link in the citation at the bottom of the page.

\begin{tabular}{|c|c|}
\hline Variable & Definition \\
\hline NYSE & $\begin{array}{l}\text { Indicator variable equal to one when the firm's common } \\
\text { stock is traded on the New York Stock Exchange }\end{array}$ \\
\hline Preferred & $\begin{array}{l}\text { Indicator variable equal to one when the company issues } \\
\text { convertible preferred stock }\end{array}$ \\
\hline Proceed & Size of the offering expressed in millions of dollars \\
\hline$Q$ & $\begin{array}{l}\text { Ratio of the market value of equity minus the book value } \\
\text { of equity plus the book value of assets to the book value } \\
\text { of assets calculated at the end of the fiscal year } \\
\text { preceding the private placement }\end{array}$ \\
\hline Qabn & $\begin{array}{l}Q \text { of the firm before the private placement corrected by } \\
\text { the median industry } Q\end{array}$ \\
\hline Rel_ceo_tenure & $\begin{array}{l}\text { Ratio between the years of CEO tenure and the years } \\
\text { from the incorporation of the company to the issue }\end{array}$ \\
\hline Ret-ew-1 & $\begin{array}{l}\text { Buy-and-hold abnormal return for the year preceding } \\
\text { the private issue calculated by subtracting the monthly } \\
\text { return of the CRSP equally-weighted index from the } \\
\text { monthly return of the firm's stock }\end{array}$ \\
\hline ROA & $\begin{array}{l}\text { Return on assets calculated at the end of the fiscal year } \\
\text { preceding the private placement }\end{array}$ \\
\hline Secur_approval & $\begin{array}{l}\text { Indicator variable equal to one when the company asks } \\
\text { for shareholder approval of the security issuance }\end{array}$ \\
\hline State_rule & $\begin{array}{l}\text { Indicator variable equal to one when the state of } \\
\text { incorporation requires shareholder approval to change } \\
\text { the maximum number of directors allowed after the } \\
\text { issuance of shares }\end{array}$ \\
\hline
\end{tabular}

Table 1. Distribution and homogeneity tests of sample firms across market, issuance, and governance characteristics

\begin{tabular}{|l|l|l|l|l|}
\hline & Full & No-App & App \\
\hline Panel A: exchange & & & \\
\hline NYSE & 24 & 14 & 10 \\
\hline AMEX & $(13.3)$ & $(9.5)$ & $(29.4)$ \\
\hline NASDAQ & 20 & 18 & 2 \\
\hline & $(11.1)$ & $(12.2)$ & $(5.9)$ \\
\hline
\end{tabular}

Journal of Corporate Finance, Vol. 13, No. 4 (September 2007): pg. 485-510. DOI. This article is (C Elsevier and permission has been granted for this version to appear in e-Publications@Marquette. Elsevier does not grant permission for this article to be further copied/distributed or hosted elsewhere without the express permission from Elsevier. 
NOT THE PUBLISHED VERSION; this is the author's final, peer-reviewed manuscript. The published version may be accessed by following the link in the citation at the bottom of the page.

\begin{tabular}{|c|c|c|c|}
\hline & Full & No-App & App \\
\hline & $(74.6)$ & $(76.9)$ & $(64.7)$ \\
\hline \multirow[t]{2}{*}{ OTC } & 2 & 2 & 0 \\
\hline & $(1.1)$ & $(1.4)$ & $(0.0)$ \\
\hline Fisher test $p$-value & & \multicolumn{2}{|l|}{0.017} \\
\hline \multicolumn{4}{|l|}{ Panel B: security } \\
\hline \multirow[t]{2}{*}{ Common } & 71 & 67 & 4 \\
\hline & (38.4) & $(44.7)$ & $(11.4)$ \\
\hline \multirow[t]{2}{*}{ Convertible preferred } & 78 & 56 & 22 \\
\hline & $(42.2)$ & $(37.3)$ & $(62.9)$ \\
\hline \multirow[t]{2}{*}{ Convertible notes } & 27 & 21 & 6 \\
\hline & $(14.6)$ & $(14.0)$ & $(17.1)$ \\
\hline \multirow[t]{2}{*}{ Loan } & 1 & 1 & 0 \\
\hline & $(0.5)$ & $(0.7)$ & $(0.0)$ \\
\hline \multirow[t]{2}{*}{ Combinations } & 8 & 5 & 3 \\
\hline & $(4.3)$ & $(3.3)$ & $(8.6)$ \\
\hline Fisher test $p$-value & & \multicolumn{2}{|l|}{0.002} \\
\hline \multicolumn{4}{|c|}{ Panel C: security approval } \\
\hline \multirow[t]{2}{*}{ No } & 119 & 110 & 9 \\
\hline & $(65.7)$ & $(74.8)$ & $(26.5)$ \\
\hline \multirow[t]{2}{*}{ Yes } & 62 & 37 & 25 \\
\hline & $(34.3)$ & $(25.2)$ & $(73.5)$ \\
\hline Fisher test $p$-value & & \multicolumn{2}{|c|}{$<0.001$} \\
\hline \multicolumn{4}{|l|}{ Panel D: investors } \\
\hline \multirow[t]{2}{*}{ Corporations } & 36 & 29 & 17 \\
\hline & $(19.4)$ & $(19.4)$ & $(20.0)$ \\
\hline \multirow[t]{2}{*}{ Individuals } & 8 & 7 & 1 \\
\hline & $(4.3)$ & $(4.7)$ & $(2.9)$ \\
\hline \multirow[t]{2}{*}{ Investment firms } & 111 & 90 & 21 \\
\hline & $(60.0)$ & $(60.0)$ & $(60.0)$ \\
\hline
\end{tabular}

Journal of Corporate Finance, Vol. 13, No. 4 (September 2007): pg. 485-510. DOI. This article is (C Elsevier and permission has been granted for this version to appear in e-Publications@Marquette. Elsevier does not grant permission for this article to be further copied/distributed or hosted elsewhere without the express permission from Elsevier. 
NOT THE PUBLISHED VERSION; this is the author's final, peer-reviewed manuscript. The published version may be accessed by following the link in the citation at the bottom of the page.

\begin{tabular}{|c|c|c|c|}
\hline & Full & No-App & App \\
\hline \multirow[t]{2}{*}{ Investment firms and individuals } & 30 & 24 & 6 \\
\hline & $(16.2)$ & $(16.0)$ & $(17.1)$ \\
\hline Fisher test $p$-value & & 0.970 & \\
\hline \multicolumn{4}{|l|}{ Panel E: directors appointed } \\
\hline \multirow[t]{2}{*}{1} & 91 & 80 & 11 \\
\hline & $(49.2)$ & $(53.3)$ & $(31.4)$ \\
\hline \multirow[t]{2}{*}{2} & 55 & 44 & 11 \\
\hline & $(29.7)$ & $(29.3)$ & $(31.4)$ \\
\hline \multirow[t]{2}{*}{3} & 17 & 10 & 7 \\
\hline & $(9.2)$ & $(6.7)$ & $(20.0)$ \\
\hline \multirow[t]{2}{*}{4} & 15 & 10 & 5 \\
\hline & $(8.1)$ & $(6.7)$ & $(14.3)$ \\
\hline \multirow[t]{2}{*}{$\geq 5$} & 7 & 6 & 1 \\
\hline & $(3.9)$ & $(4.0)$ & $(2.9)$ \\
\hline Fisher test $p$-value & & 0.034 & \\
\hline \multicolumn{4}{|l|}{ Panel F: impact on board size } \\
\hline \multirow[t]{2}{*}{ Addition } & 117 & 98 & 19 \\
\hline & $(63.2)$ & $(65.3)$ & $(54.3)$ \\
\hline \multirow[t]{2}{*}{ Replacement } & 52 & 40 & 12 \\
\hline & $(28.1)$ & $(26.7)$ & $(34.3)$ \\
\hline \multirow[t]{2}{*}{ Mixed } & 16 & 12 & 4 \\
\hline & $(8.6)$ & $(8.0)$ & $(11.4)$ \\
\hline Fisher test $p$-value & & 0.468 & \\
\hline
\end{tabular}

"Full" refers to a sample of 181 U.S. firms that appoint directors in combination with private offerings between 1995 and 2000. "No-App" refers to the subsample of firms that appoint directors without shareholder approval, and "App" refers to the subsample of firms that appoint directors with shareholder approval. The percentage of firms in each group is reported in parenthesis. The $p$-values for Fisher's exact tests of homogeneity between the two approval subsamples are reported at the bottom of each panel. 
Table 2. Firm characteristics, issue characteristics, governance, and past performance variables for the full sample, the subsample formed by firms that appoint directors without shareholder approval ("No-App"), and that with shareholder approval ("App")

\begin{tabular}{|c|c|c|c|c|c|c|}
\hline & $\begin{array}{c}\text { Full } \\
\text { sample }\end{array}$ & No-App & App & Diff & $\begin{array}{c}t \text {-stat or } \\
\text { Chi- } \\
\text { Square } \\
\text { (Wilc.Z) }\end{array}$ & $\begin{array}{c}p- \\
\text { value }\end{array}$ \\
\hline \multicolumn{7}{|c|}{ Panel A: firm characteristics } \\
\hline \multirow[t]{2}{*}{ Assets } & 217.0 & 165.6 & 438.9 & 273.3 & 2.45 & 0.019 \\
\hline & $(47.3)$ & $(37.0)$ & $(142.4)$ & $(105.4)$ & $(2.45)$ & $(0.014)$ \\
\hline \multirow[t]{2}{*}{ Marketcap } & 182.8 & 185.5 & 154.0 & -31.51 & -0.47 & 0.643 \\
\hline & $(53.4)$ & $(45.5)$ & $(77.8)$ & $(32.3)$ & $(1.85)$ & $(0.065)$ \\
\hline \multirow[t]{2}{*}{ Age } & 6.17 & 5.75 & 7.97 & 2.22 & 1.60 & 0.117 \\
\hline & $(4.14)$ & $(4.02)$ & $(6.01)$ & $(1.98)$ & $(1.64)$ & $(0.100)$ \\
\hline \multirow[t]{2}{*}{ Freecash/assets } & -0.23 & -0.22 & {$[-0.27$} & -0.055 & -0.50 & 0.623 \\
\hline & $(-0.04)$ & $(-0.05)$ & $(-0.04)$ & $(0.01)$ & $(-0.03)$ & $(0.974)$ \\
\hline \multirow[t]{2}{*}{ Leverage } & 0.29 & 0.28 & 0.33 & 0.052 & 1.29 & 0.204 \\
\hline & $(0.24)$ & $(0.23)$ & $(0.29)$ & $(0.06)$ & $(1.11)$ & $(0.269)$ \\
\hline \multicolumn{7}{|c|}{ Panel B: issue characteristics } \\
\hline \multirow[t]{2}{*}{ Fraction_placed } & 0.26 & 0.24 & 0.32 & 0.08 & 2.53 & 0.012 \\
\hline & $(0.20)$ & $(0.19)$ & $(0.31)$ & $(0.12)$ & $(3.02)$ & $(0.003)$ \\
\hline \multirow[t]{2}{*}{ Proceed } & 46.74 & 42.56 & 64.81 & 22.24 & 0.80 & 0.424 \\
\hline & $(10.00)$ & $(9.60)$ & $(27.50)$ & $(17.90)$ & $(3.04)$ & $(0.003)$ \\
\hline \multirow[t]{2}{*}{ Dir_appointed } & 1.89 & 1.79 & 2.32 & 0.53 & 2.43 & 0.016 \\
\hline & (2) & (1) & $(2)$ & (1) & $(2.83)$ & $(0.005)$ \\
\hline \multirow[t]{2}{*}{ Board_size_change } & 0.25 & 0.24 & 0.29 & 0.043 & 1.46 & 0.147 \\
\hline & $(0.20)$ & $(0.20)$ & $(0.25)$ & $(0.05)$ & -2.17 & $(0.030)$ \\
\hline \multicolumn{7}{|l|}{ Panel C: governance } \\
\hline \multirow[t]{2}{*}{ Board_size } & 6.53 & 6.39 & 7.12 & 0.72 & 1.92 & 0.057 \\
\hline & (6) & (6) & (7) & (1) & $(2.12)$ & $(0.034)$ \\
\hline \multirow[t]{2}{*}{ Ceochair } & 0.54 & 0.57 & 0.41 & -0.16 & 2.84 & 0.092 \\
\hline & na & na & na & na & na & na \\
\hline
\end{tabular}

Journal of Corporate Finance, Vol. 13, No. 4 (September 2007): pg. 485-510. DOI. This article is (C) Elsevier and permission has been granted for this version to appear in e-Publications@Marquette. Elsevier does not grant permission for this article to be further copied/distributed or hosted elsewhere without the express permission from Elsevier. 
NOT THE PUBLISHED VERSION; this is the author's final, peer-reviewed manuscript. The published version may be accessed by following the link in the citation at the bottom of the page.

\begin{tabular}{|c|c|c|c|c|c|c|}
\hline & \begin{tabular}{|c|} 
Full \\
sample
\end{tabular} & No-App & App & Diff & $\begin{array}{c}t \text {-stat or } \\
\text { Chi- } \\
\text { Square } \\
\text { (Wilc.Z) }\end{array}$ & $\begin{array}{c}p- \\
\text { value }\end{array}$ \\
\hline \multirow[t]{2}{*}{ Insiderchair } & 0.68 & 0.73 & 0.47 & -0.26 & 8.40 & 0.004 \\
\hline & na & na & na & na & na & na \\
\hline \multirow[t]{2}{*}{ Insiders } & 0.32 & 0.33 & 0.27 & -0.06 & -1.68 & 0.095 \\
\hline & $(0.29)$ & $(0.29)$ & $(0.25)$ & $(-0.04)$ & $(-2.00)$ & $(0.046)$ \\
\hline \multirow[t]{2}{*}{ Founder } & 0.33 & 0.31 & 0.41 & 0.10 & 1.22 & 0.269 \\
\hline & na & na & na & na & na & na \\
\hline \multirow[t]{2}{*}{ Insider_own } & 0.22 & 0.22 & 0.24 & 0.01 & 0.46 & 0.643 \\
\hline & $(0.19)$ & $(0.18)$ & $(0.20)$ & $(0.02)$ & $(0.56)$ & $(0.575)$ \\
\hline \multirow[t]{2}{*}{ Inst_own } & 0.20 & 0.18 & 0.28 & 0.09 & 1.84 & 0.074 \\
\hline & $(0.13)$ & $(0.11)$ & $(0.23)$ & $(0.11)$ & $(1.61)$ & $(0.117)$ \\
\hline \multicolumn{7}{|c|}{ Panel D: past performance } \\
\hline \multirow[t]{2}{*}{$Q$} & 2.86 & 3.04 & 2.07 & -0.97 & -1.65 & 0.102 \\
\hline & $(1.50)$ & $(1.60)$ & $(1.20)$ & $(-0.40)$ & $(-2.43)$ & $(0.015)$ \\
\hline \multirow[t]{2}{*}{ Qabn } & 1.02 & 1.13 & 0.58 & -0.55 & -0.98 & 0.328 \\
\hline & $(-0.06)$ & $(-0.03)$ & $(-0.15)$ & $(-0.11)$ & $(-0.78)$ & $(0.436)$ \\
\hline \multirow[t]{2}{*}{ ROA } & -0.31 & -0.17 & -0.16 & 0.00 & 0.05 & 0.962 \\
\hline & $(-0.03)$ & $(-0.04)$ & $(-0.01)$ & $(0.03)$ & $(-0.26)$ & $(0.795)$ \\
\hline \multirow[t]{2}{*}{ Ret-ew-1 } & -0.17 & -0.14 & -0.30 & -0.16 & -0.70 & 0.485 \\
\hline & $(-0.55)$ & $(-0.55)$ & $(-0.56)$ & $(-0.01)$ & $(-0.15)$ & $(0.877)$ \\
\hline
\end{tabular}

The table presents the $t$-statistics and $p$-values of the difference of the means, and the Wilcoxon $z$-statistics and $p$-values of the Wilcoxon-Mann-Whitney non-parametric test. For indicator variables we report chi-square statistics and its corresponding $p$ values. Statistically significant differences, at a minimum $10 \%$ confidence level, are reported in bold. All variables are defined in the Appendix.

Table 3. Determinants of shareholder approval - probit regressions

\begin{tabular}{|c|c|c|c|c|c|c|c|c|c|c|c|}
\hline & (1) & (2) & (3) & (4) & (5) & (6) & (7) & $(8)$ & (9) & $(\mathbf{1 0})$ & (11) \\
\hline \multirow[t]{2}{*}{ Intercept } & -1.266 & -1.774 & $=1.668$ & - 1.884 & - 1.711 & -1.708 & -1.706 & -1.737 & - 1.587 & - 1.709 & - 1.588 \\
\hline & $(0.042)$ & $(0.005)$ & $(0.010)$ & $(0.006)$ & $(<0.001)$ & $(<0.001)$ & $(<0.001)$ & $(<.0001)$ & $(<0.001)$ & $(<0.001)$ & $(0.001)$ \\
\hline \multirow[t]{2}{*}{ Board_size } & -0.010 & 0.002 & $=0.006$ & -0.021 & & & & & & & \\
\hline & $(0.873)$ & $(0.979)$ & $(0.924)$ & $(0.759)$ & & & & & & & \\
\hline
\end{tabular}

Journal of Corporate Finance, Vol. 13, No. 4 (September 2007): pg. 485-510. DOI. This article is @ Elsevier and permission has been granted for this version to appear in e-Publications@Marquette. Elsevier does not grant permission for this article to be further copied/distributed or hosted elsewhere without the express permission from Elsevier. 
NOT THE PUBLISHED VERSION; this is the author's final, peer-reviewed manuscript. The published version may be accessed by following the link in the citation at the bottom of the page.

\begin{tabular}{|c|c|c|c|c|c|c|c|c|c|c|c|}
\hline & (1) & (2) & (3) & (4) & (5) & (6) & (7) & (8) & (9) & (10) & (11) \\
\hline \multirow[t]{2}{*}{ Insiders } & -0.545 & & -0.065 & 0.084 & & & & & & & \\
\hline & $(0.489)$ & & $(0.403)$ & $(0.921)$ & & & & & & & \\
\hline \multirow[t]{2}{*}{ Insiderchair } & -0.650 & -0.631 & -0.805 & -0.985 & -0.798 & -0.811 & -0.806 & -0.804 & -0.794 & -0.789 & -0.790 \\
\hline & $(0.007)$ & $(0.008)$ & $(0.001)$ & $(<0.001)$ & $(0.001)$ & $(0.001)$ & $(0.001)$ & $(0.001)$ & $(0.001)$ & $(0.001)$ & $(0.004)$ \\
\hline \multirow[t]{2}{*}{ Insider_ownership } & 0.867 & 1.024 & & & & & & & & & \\
\hline & $(0.187)$ & $(0.136)$ & & & & & & & & & \\
\hline \multirow[t]{2}{*}{ Rel_ceo_tenure } & 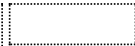 & -0.0591 & & & & & & & & & \\
\hline & & $(0.136)$ & & & & & & & & & \\
\hline \multirow[t]{2}{*}{ Freecash/assets 1} & & & & & & & & & & -1.798 & -2.016 \\
\hline & & & & & & & & & & $(0.082)$ & $(0.096)$ \\
\hline \multirow[t]{2}{*}{ Lnassets } & 0.193 & 0.178 & 0.191 & 0.250 & 0.167 & 0.188 & 0.197 & 0.186 & 0.144 & 0.202 & 0.164 \\
\hline & $(0.005)$ & $(0.009)$ & $(0.006)$ & $(0.001)$ & $(0.025)$ & $(0.004)$ & $(0.005)$ & $(0.004)$ & $(0.053)$ & $(0.002)$ & $(0.035)$ \\
\hline \multirow[t]{2}{*}{ Fraction_placed } & & & 1.994 & & 2.003 & 1.991 & 1.998 & 1.841 & 1.899 & 1.952 & 1.116 \\
\hline & & & $(0.005)$ & & $(0.004)$ & $(0.004)$ & $(0.004)$ & $(0.040)$ & $(0.007)$ & $(0.005)$ & $(0.162)$ \\
\hline \multirow[t]{2}{*}{ State_rule } & & & & 1.028 & & & & & & & 1.318 \\
\hline & & & & $(0.010)$ & & & & & & & $(0.002)$ \\
\hline \multirow[t]{2}{*}{ Inst_ownership } & & & & & 0.004 & & & & & & \\
\hline & & & & & $(0.979)$ & & & & & & \\
\hline \multirow[t]{2}{*}{ Qabn } & 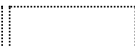 & & & & & $=0.005$ & & & & & \\
\hline & & & & & & $(0.866)$ & & & & & \\
\hline \multirow[t]{2}{*}{ Leverage } & & & & & & & -0.106 & & & & 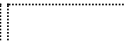 \\
\hline & & & & & & & $(0.826)$ & & & & 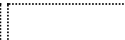 \\
\hline \multirow[t]{2}{*}{ Directors_appointed } & & & & & & 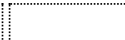 & & 0.035 & & & 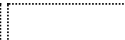 \\
\hline & & & & & & & & $(0.775)$ & & & \\
\hline \multirow[t]{2}{*}{ NYSE } & & & & & & & & & 0.428 & & 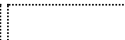 \\
\hline & & & & & & & & & $(0.231)$ & & 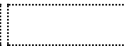 \\
\hline \multirow[t]{2}{*}{ Common } & & & & & 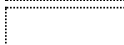 & 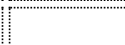 & & 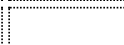 & 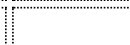 & I & -0.817 \\
\hline & & & & & & & & & I & & $(0.039)$ \\
\hline \multirow[t]{2}{*}{ Preferred } & & & & & 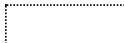 & 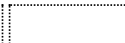 & & 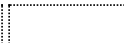 & 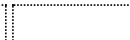 & 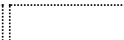 & 0.057 \\
\hline & & & & & 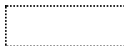 & & & 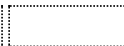 & II & 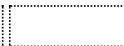 & $(0.854)$ \\
\hline \multirow[t]{2}{*}{ Secur_approval } & & & & 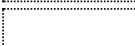 & 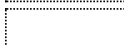 & & & 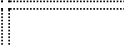 & 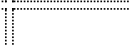 & 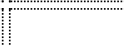 & 0.618 \\
\hline & & & & 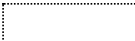 & I & & & & 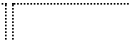 & & $(0.002)$ \\
\hline Goodness of fit & 1.10 & 1.10 & 1.19 & 1.21 & 1.19 & 1.18 & 1.15 & 1.17 & 1.20 & 1.22 & 1.33 \\
\hline Log-likelihood & -78.1 & -77.1 & -75.0 & -71.8 & -74.8 & -75.0 & -75.0 & -74.9 & -74.3 & -74.7 & -64.2 \\
\hline
\end{tabular}

The dependent variable is an indicator variable that is equal to one when the firm asks for shareholder approval to appoint representatives of the private investors to the board. Comparable to Palia (2001) and Fama and French (2002) we set the missing observations of Compustat variables to zero and use indicator variables that are set to unity for the missing observations. Goodness of fit is calculated as in McIntosh and Dorfman (1992). The $p$-values of the coefficients are reported in parenthesis. Statistically significant coefficients, at a minimum $10 \%$ confidence level, are reported in bold. All independent variables are defined in the Appendix.

Journal of Corporate Finance, Vol. 13, No. 4 (September 2007): pg. 485-510. DOI. This article is @ Elsevier and permission has been granted for this version to appear in e-Publications@Marquette. Elsevier does not grant permission for this article to be further copied/distributed or hosted elsewhere without the express permission from Elsevier. 
NOT THE PUBLISHED VERSION; this is the author's final, peer-reviewed manuscript. The published version may be accessed by following the link in the citation at the bottom of the page.

Table 4. Monitoring role of appointed directors - univariate analysis

\begin{tabular}{|c|c|c|c|c|c|c|c|c|c|c|}
\hline \multirow[b]{2}{*}{ Variable } & \multicolumn{3}{|c|}{ No-approval } & \multicolumn{3}{|c|}{ Approval } & \multicolumn{4}{|c|}{ Difference } \\
\hline & $\boldsymbol{N}$ & Mean & Median & $\mathbf{N}$ & Mean & Median & Mean & $\begin{array}{c}p- \\
\text { value }\end{array}$ & Median & $\begin{array}{c}p- \\
\text { value }\end{array}$ \\
\hline Independent & 151 & 1.14 & 1 & 30 & 1.87 & 2 & 0.73 & 0.002 & 1 & 0.004 \\
\hline Fraction_ind & 151 & 0.15 & 0.14 & 30 & 0.24 & 0.22 & 0.08 & 0.005 & 0.08 & 0.011 \\
\hline Chair & 145 & 0.09 & na & 30 & 0.20 & na & 0.11 & 0.089 & na & na \\
\hline Ind_chair & 145 & 0.05 & na & 30 & 0.17 & na & 0.12 & 0.025 & na & na \\
\hline Committee & 139 & 0.21 & 0.20 & 29 & 0.23 & 0.24 & 0.02 & 0.546 & 0.04 & 0.355 \\
\hline Audit & 139 & 0.22 & 0.25 & 29 & 0.21 & 0.33 & -0.01 & 0.898 & 0.08 & 0.859 \\
\hline Compensation & 139 & 0.19 & 0.00 & 29 & 0.21 & 0.25 & 0.02 & 0.748 & 0.25 & 0.580 \\
\hline
\end{tabular}

The $p$-values refer to two-sample $t$-tests for the mean, WilcoxonMann-Whitney non-parametric tests for the median, and chi-square tests for indicator variables (i.e., Chair and Ind_chair). Statistically significant differences, at a minimum 10\% confidence level, are reported in bold. All variables are defined in the Appendix.

Table 5. Monitoring role of appointed directors - multivariate analysis

\begin{tabular}{|c|c|c|c|c|c|c|}
\hline & (1) & (2) & (3) & (4) & (5) & (6) \\
\hline \multicolumn{7}{|c|}{ Panel A: fraction of independent appointed directors } \\
\hline \multirow[t]{2}{*}{ Intercept } & 0.118 & 0.108 & 0.208 & 0.129 & 0.129 & 0.142 \\
\hline & $\begin{array}{l}(<0.00 \\
1)\end{array}$ & $(0.008)$ & $\begin{array}{l}(<0.00 \\
1)\end{array}$ & $(0.013)$ & $(0.013)$ & $(0.006)$ \\
\hline \multirow[t]{2}{*}{ Approval } & 0.101 & 0.117 & 0.119 & 0.085 & 0.080 & 0.076 \\
\hline & $(0.009)$ & $(0.003)$ & $(0.002)$ & $(0.014)$ & $(0.032)$ & $(0.046)$ \\
\hline \multirow[t]{2}{*}{ Lnassets } & & -0.005 & 0.002 & -0.003 & -0.003 & -0.007 \\
\hline & & $(0.523)$ & $(0.787)$ & $(0.732)$ & $(0.709)$ & $(0.400)$ \\
\hline \multirow[t]{2}{*}{ Insidechair } & & 0.052 & 0.043 & 0.035 & 0.035 & 0.037 \\
\hline & & $(0.103)$ & $(0.165)$ & $(0.212)$ & $(0.204)$ & $(0.192)$ \\
\hline \multirow{2}{*}{$\begin{array}{l}\text { Freecash/assets } \\
1\end{array}$} & & -0.199 & -0.258 & -0.209 & -0.203 & -0.211 \\
\hline & & $(0.496)$ & $(0.373)$ & $(0.415)$ & $(0.429)$ & $(0.408)$ \\
\hline Board_size & & & $\begin{array}{l}-0.01 \\
9\end{array}$ & $\begin{array}{l}-0.01 \\
9\end{array}$ & $\begin{array}{l}-0.01 \\
9\end{array}$ & ]$_{8}^{-0.01}$ \\
\hline
\end{tabular}

Journal of Corporate Finance, Vol. 13, No. 4 (September 2007): pg. 485-510. DOI. This article is (C Elsevier and permission has been granted for this version to appear in e-Publications@Marquette. Elsevier does not grant permission for this article to be further copied/distributed or hosted elsewhere without the express permission from Elsevier. 


\begin{tabular}{|c|c|c|c|c|c|c|}
\hline & (1) & (2) & (3) & (4) & (5) & (6) \\
\hline \multicolumn{7}{|c|}{ Panel A: fraction of independent appointed directors } \\
\hline & & & $(0.014)$ & $(0.004)$ & $(0.004)$ & $(0.006)$ \\
\hline \multirow{2}{*}{$\begin{array}{l}\text { Number_appoin } \\
\text { ted }\end{array}$} & & & & 0.061 & 0.061 & 0.060 \\
\hline & & & & $\begin{array}{l}(<0.00 \\
1)\end{array}$ & $\begin{array}{l}(<0.00 \\
1)\end{array}$ & $\begin{array}{l}(<0.00 \\
1)\end{array}$ \\
\hline \multirow[t]{2}{*}{ Secur_approval } & & & & & 0.013 & 0.023 \\
\hline & & & & & $(0.669)$ & $(0.454)$ \\
\hline \multirow[t]{2}{*}{ Q_abn } & & & & & & -0.00 \\
\hline & & & & & & $(0.099)$ \\
\hline \multirow[t]{2}{*}{ State_rule } & & & & & & -0.015 \\
\hline & & & & & & $(0.731)$ \\
\hline Log-likelihood & -15.32 & -12.00 & -9.02 & 5.02 & 5.08 & 6.53 \\
\hline \multicolumn{7}{|c|}{ Panel B: one of the independent appointed directors is chairman } \\
\hline \multirow[t]{2}{*}{ Intercept } & $\mid-1.59$ & $\begin{array}{l}-1.90 \\
1\end{array}$ & $\mid \begin{array}{l}-2.00 \\
0\end{array}$ & 8 & $\mid-2.12$ & $7^{-2.19}$ \\
\hline & $\begin{array}{l}(<0.00 \\
1)\end{array}$ & $\begin{array}{l}(<0.00 \\
1)\end{array}$ & $(0.001)$ & $\begin{array}{l}(<0.00 \\
1)\end{array}$ & $\begin{array}{l}(<0.00 \\
1)\end{array}$ & $(0.001)$ \\
\hline \multirow[t]{2}{*}{ Approval } & 0.629 & 0.846 & 0.842 & 0.747 & 0.948 & 0.943 \\
\hline & $(0.050)$ & $(0.021)$ & $(0.021)$ & $(0.049)$ & $(0.031)$ & $(0.043)$ \\
\hline \multirow[t]{2}{*}{ Lnassets } & & -0.060 & -0.068 & -0.079 & -0.071 & {$[-0.094$} \\
\hline & & $(0.465)$ & $(0.444)$ & $(0.374)$ & $(0.428)$ & $(0.355)$ \\
\hline \multirow[t]{2}{*}{ Insidechair } & & 0.482 & 0.491 & 0.463 & 0.428 & 0.415 \\
\hline & & $(0.199)$ & $(0.193)$ & $(0.239)$ & $(0.283)$ & $(0.310)$ \\
\hline \multirow{2}{*}{$\begin{array}{l}\text { Freecash/assets } \\
1\end{array}$} & & 1.596 & 1.633 & 1.853 & 1.382 & 1.423 \\
\hline & & $(0.576)$ & $(0.568)$ & $(0.536)$ & $(0.655)$ & $(0.658)$ \\
\hline \multirow[t]{3}{*}{ Board_size } & & & 0.019 & -0.004 & {$[-0.004$} & 0.004 \\
\hline & & & $(0.815)$ & $(0.961)$ & $(0.963)$ & $(0.963)$ \\
\hline & & & & 0.248 & 0.268 & 0.272 \\
\hline
\end{tabular}

Journal of Corporate Finance, Vol. 13, No. 4 (September 2007): pg. 485-510. DOI. This article is (C Elsevier and permission has been granted for this version to appear in e-Publications@Marquette. Elsevier does not grant permission for this article to be further copied/distributed or hosted elsewhere without the express permission from Elsevier. 


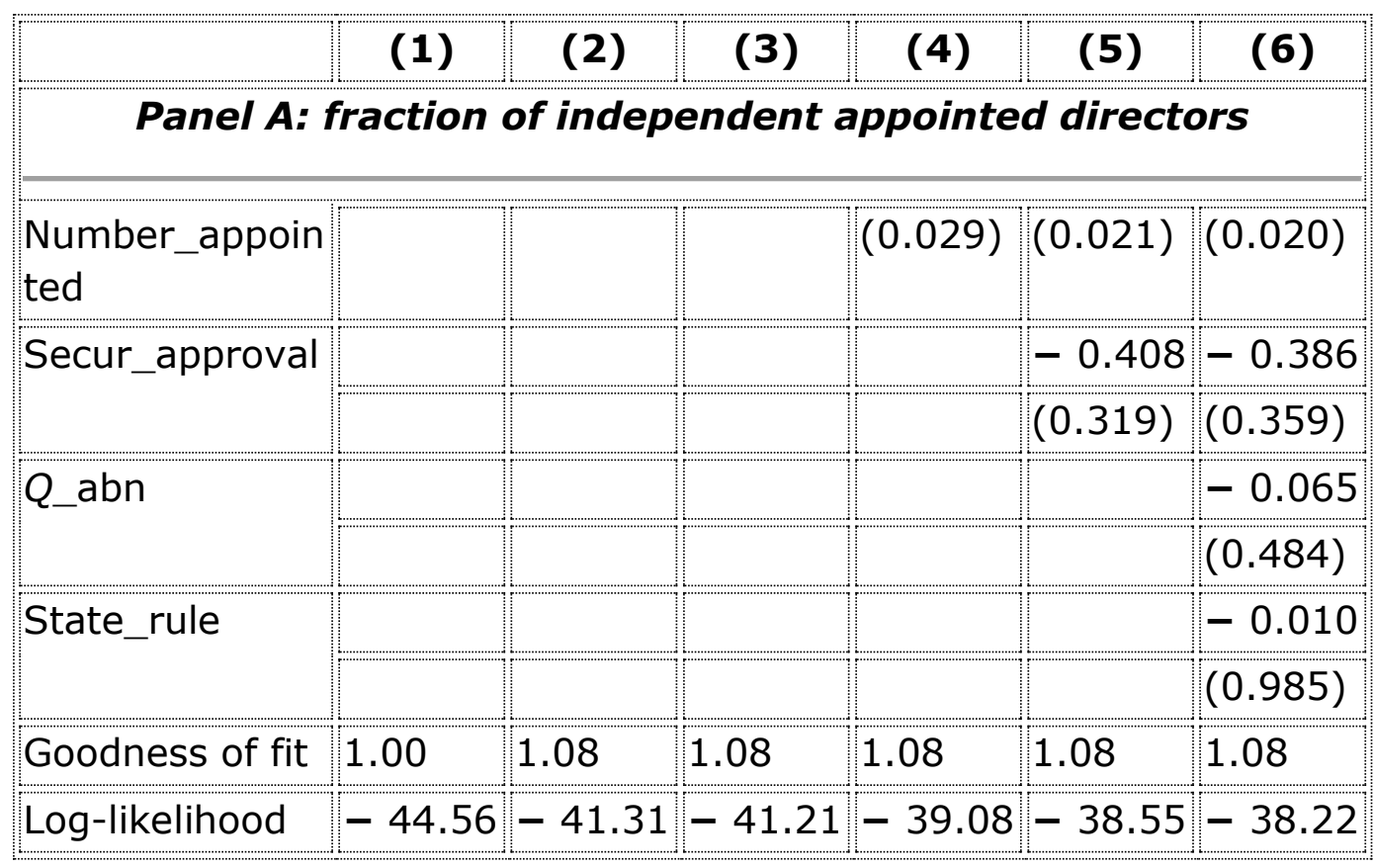

Panel A presents the coefficients of a Tobit regression in which the dependent variable is the number of independent appointed directors divided by the board size after the placement. Panel B presents the coefficients of a probit regression in which the dependent variable is an indicator variable equal to one when one of the independent directors appointed in connection with the private placement is also appointed chairman of the board. Goodness of fit is calculated as in McIntosh and Dorfman (1992). The $p$-values of the coefficients are reported in parenthesis. Statistically significant coefficients, at a minimum $10 \%$ confidence level, are reported in bold. All independent variables are defined in the Appendix.

Table 6. Abnormal announcement returns

\begin{tabular}{|c|c|c|c|c|c|}
\hline & CAAR (\%) & Pos:Neg & $\boldsymbol{Z}$ & $\operatorname{scs} Z$ & $\boldsymbol{t}$ \\
\hline \multicolumn{6}{|c|}{ Panel $A$ : full sample $(N=171)$} \\
\hline$(0,1)$ & 5.58 & $104: 67$ & 9.294 & 4.551 & 7.765 \\
\hline$(-2,2)$ & 10.16 & $115: 56$ & 10.430 & 6.296 & 8.942 \\
\hline$(-1,1)$ & 7.48 & $116: 55$ & 9.851 & 5.689 & 8.498 \\
\hline \multicolumn{6}{|c|}{ Panel B: no-approval sample $(N=139)$} \\
\hline$(0,1)$ & 4.96 & $84: 55$ & 7.870 & 3.766 & 6.288 \\
\hline$(-2,2)$ & 10.06 & $91: 48$ & 9.684 & 5.543 & 8.068 \\
\hline$(-1,1)$ & 7.01 & $94: 45$ & 8.616 & 4.819 & 7.253 \\
\hline
\end{tabular}


NOT THE PUBLISHED VERSION; this is the author's final, peer-reviewed manuscript. The published version may be accessed by following the link in the citation at the bottom of the page.

\begin{tabular}{|l|l|l|l|l|l|}
\hline \multicolumn{7}{|c|}{ CAAR (\%) } & Pos:Neg & \multicolumn{1}{|c|}{$\boldsymbol{Z}$} & SCS Z & $\boldsymbol{t}$ \\
\hline Panel C: approval sample (N=32) \\
\hline$(0,1)$ & 8.27 & $20: 12$ & 5.084 & 2.764 & 5.607 \\
\hline$(-2,2)$ & 10.58 & $24: 8$ & 3.926 & 3.263 & 4.536 \\
\hline$(-1,1)$ & 9.53 & $22: 10$ & 4.814 & 3.247 & 5.273 \\
\hline
\end{tabular}

We calculate the abnormal announcement returns by means of a market model with an estimation period of 253 days that terminates 46 days before the announcement. The full sample is formed only by firms that announce the private placement and appointment of directors on the same day. The market returns used in the model are the CRSP equally-weighted returns. CAAR is the cumulative average abnormal return, pos:neg is the number of firms with positive:negative abnormal returns, $Z$ is the $Z$ statistics of the Patell (1976) test, SCS $Z$ is the $z$ statistics of the Boehmer et al. (1991) test, and $t$ is the $t$-statistic with the time series correction of Brown and Warner (1985).

Table 7. Abnormal announcement returns - OLS regressions

\begin{tabular}{|c|c|c|c|c|c|c|}
\hline & (1) & (2) & (3) & (4) & (5) & (6) \\
\hline \multirow{2}{*}{ Intercept } & 0.049 & 0.064 & 0.052 & 0.048 & 0.047 & -0.010 \\
\hline & $(<0.001)$ & $(0.015)$ & $(0.020)$ & $(0.063)$ & $(0.208)$ & $(0.843)$ \\
\hline \multirow{2}{*}{ Approval } & 0.044 & 0.063 & 0.076 & 0.076 & 0.066 & 0.065 \\
\hline & $(0.163)$ & $(0.058)$ & $(0.028)$ & $(0.028)$ & $(0.060)$ & $(0.074)$ \\
\hline \multirow{2}{*}{ Secur_approval } & & -0.046 & -0.046 & -0.048 & -0.044 & -0.043 \\
\hline & & $(0.070)$ & $(0.074)$ & $(0.070)$ & $(0.105)$ & $(0.114)$ \\
\hline \multirow{2}{*}{ Fraction_ind } & & & 0.005 & -0.008 & -0.015 & 0.016 \\
\hline & & & $(0.955)$ & $(0.927)$ & $(0.871)$ & $(0.876)$ \\
\hline \multirow{2}{*}{ Board_size_change } & & & 0.064 & 0.062 & 0.076 & 0.062 \\
\hline & & & $(0.450)$ & $(0.467)$ & $(0.382)$ & $(0.470)$ \\
\hline \multirow{2}{*}{ Fraction_placed } & & & & 0.031 & 0.001 & -0.007 \\
\hline & & & & $(0.725)$ & $(0.994)$ & $(0.946)$ \\
\hline \multirow{2}{*}{ Delta_offdir_own } & & & & & 0.041 & 0.057 \\
\hline & & & & & $(0.630)$ & $(0.519)$ \\
\hline \multirow{2}{*}{ Delta_inst_own } & & & & & 0.065 & 0.055 \\
\hline & & & & & $(0.457)$ & $(0.541)$ \\
\hline \multirow{2}{*}{ Lnassets } & & & & & 0.002 & 0.007 \\
\hline & & & & & $(0.457)$ & $(0.385)$ \\
\hline
\end{tabular}

Journal of Corporate Finance, Vol. 13, No. 4 (September 2007): pg. 485-510. DOI. This article is (C Elsevier and permission has been granted for this version to appear in e-Publications@Marquette. Elsevier does not grant permission for this article to be further copied/distributed or hosted elsewhere without the express permission from Elsevier. 
NOT THE PUBLISHED VERSION; this is the author's final, peer-reviewed manuscript. The published version may be accessed by following the link in the citation at the bottom of the page.

\begin{tabular}{|c|c|c|c|c|c|c|}
\hline & (1) & (2) & (3) & (4) & (5) & (6) \\
\hline \multirow{2}{*}{ Common } & & & & & & 0.055 \\
\hline & & & & & & $(0.103)$ \\
\hline \multirow{2}{*}{ Preferred } & & & & & & 0.023 \\
\hline & & & & & & $(0.480)$ \\
\hline \multirow{2}{*}{ Freecash/assets1 } & & & & & & -0.213 \\
\hline & & & & & & $(0.378)$ \\
\hline \multirow{2}{*}{ Alliance } & & & & & & 0.021 \\
\hline & & & & & & $(0.542)$ \\
\hline \multirow{2}{*}{ State_rule } & & & & & & 0.012 \\
\hline & & & & & & $(0.792)$ \\
\hline Adjusted $R^{2}$ & 0.006 & 0.019 & 0.017 & 0.012 & 0.051 & 0.024 \\
\hline
\end{tabular}

The dependent variable is the cumulative average abnormal return (CAAR) for the announcement day and the following day (interval $[0,1]$ ). The $p$-values of the coefficients are reported in parenthesis. Statistically significant coefficients, at a minimum $10 \%$ confidence level, are reported in bold. All independent variables are defined in the Appendix.

Table 8. Discount-adjusted abnormal returns

\begin{tabular}{|c|c|c|c|c|c|c|}
\hline \multicolumn{7}{|c|}{ Panel A: univariate analysis } \\
\hline 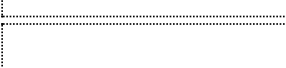 & \multicolumn{2}{|c|}{ DAAR } & t-stat & \multicolumn{2}{|c|}{$p$-value } & $N$ \\
\hline Full & \multicolumn{2}{|l|}{11.60} & 3.68 & \multicolumn{2}{|l|}{0.005} & 67 \\
\hline No-app & \multicolumn{2}{|l|}{9.33} & 3.24 & \multicolumn{2}{|l|}{0.002} & 61 \\
\hline App & \multicolumn{2}{|l|}{38.82} & 1.94 & \multicolumn{2}{|l|}{0.109} & 6 \\
\hline Diff & 29.50 & \multicolumn{2}{|c|}{2.60} & \multicolumn{2}{|l|}{0.012} & \\
\hline \multicolumn{7}{|c|}{ Panel B: multivariate analysis } \\
\hline & (1) & (2) & (3) & (4) & (5) & (6) \\
\hline \multirow[t]{2}{*}{ Intercept } & 0.093 & 0.107 & 0.140 & 0.129 & -0.033 & -0.150 \\
\hline & $(0.004)$ & $(0.007)$ & $(0.016)$ & $(0.078)$ & $(0.205)$ & $(0.492)$ \\
\hline \multirow[t]{2}{*}{ Approval } & 0.295 & 0.323 & 0.329 & 0.329 & 0.333 & 0.375 \\
\hline & $(0.012)$ & $(0.011)$ & $(0.011)$ & $(0.012)$ & $(0.021)$ & $(0.019)$ \\
\hline Secur_approval & & -0.042 & -0.065 & -0.071 & -0.037 & -0.016 \\
\hline
\end{tabular}

Journal of Corporate Finance, Vol. 13, No. 4 (September 2007): pg. 485-510. DOI. This article is @ Elsevier and permission has been granted for this version to appear in e-Publications@Marquette. Elsevier does not grant permission for this article to be further copied/distributed or hosted elsewhere without the express permission from Elsevier. 
NOT THE PUBLISHED VERSION; this is the author's final, peer-reviewed manuscript. The published version may be accessed by following the link in the citation at the bottom of the page.

\begin{tabular}{|c|c|c|c|c|c|c|}
\hline \multicolumn{7}{|c|}{ Panel B: multivariate analysis } \\
\hline & (1) & (2) & (3) & (4) & (5) & (6) \\
\hline & & $(0.537)$ & $(0.364)$ & $(0.351)$ & $(0.664)$ & $(0.858)$ \\
\hline \multirow[t]{2}{*}{ Fraction_ind } & & & 0.310 & 0.311 & 0.210 & 0.068 \\
\hline & & & $(0.292)$ & $(0.293)$ & $(0.522)$ & $(0.879)$ \\
\hline \multirow[t]{2}{*}{ Dir_change } & & & -0.309 & -0.314 & -0.244 & -0.154 \\
\hline & & & $(0.138)$ & $(0.137)$ & $(0.275)$ & $(0.522)$ \\
\hline \multirow[t]{2}{*}{ Fraction_placed } & & & & 0.065 & 0.036 & -0.039 \\
\hline & & & & $(0.803)$ & $(0.903)$ & $(0.896)$ \\
\hline \multirow[t]{2}{*}{ Common } & & & & & 0.121 & 0.214 \\
\hline & & & & & $(0.471)$ & $(0.235)$ \\
\hline \multirow[t]{2}{*}{ Delta_offdir_own } & & & & & 0.164 & 0.197 \\
\hline & & & & & $(0.586)$ & $(0.533)$ \\
\hline \multirow[t]{2}{*}{ Delta_inst_own } & & & & & 0.261 & 0.236 \\
\hline & & & & & $(0.364)$ & $(0.418)$ \\
\hline \multirow[t]{2}{*}{ Lnassets } & & & & & 0.010 & 0.028 \\
\hline & & & & & $(0.675)$ & $(0.350)$ \\
\hline \multirow[t]{2}{*}{ Freecash/assets1 } & & & & & & -1.050 \\
\hline & & & & & & $(0.233)$ \\
\hline \multirow[t]{2}{*}{ Alliance } & & & & & & 0.015 \\
\hline & & & & & & $(0.892)$ \\
\hline \multirow[t]{2}{*}{ State_rule } & & & & & & -0.023 \\
\hline & & & & & & $(0.814)$ \\
\hline Adjusted $R^{2}$ & 0.083 & 0.103 & 0.082 & 0.068 & 0.020 & 0.027 \\
\hline
\end{tabular}

Panel A presents the discount-adjusted abnormal return (DAARs) calculated as in Wruck (1989) and Hertzel and Smith (1993). "Full" refers to the full sample, "No-app" refers to the subsample of firms that appoint directors without shareholder approval, and "App" refers to the subsample of firms that appoint directors with shareholder approval. "Diff" is the difference between the DAARs of the two approval subsamples. The sample is formed only by firms that privately issue common stock and announce the private offering and the board appointments on the same day. Panel B presents the coefficients of OLS regressions in which the dependent variable is the DAAR. The $p$-values of the coefficients are reported in parenthesis. Statistically significant coefficients, at a minimum $10 \%$ confidence level, are reported in bold. All independent variables are defined in the Appendix.

Journal of Corporate Finance, Vol. 13, No. 4 (September 2007): pg. 485-510. DOI. This article is (C) Elsevier and permission has been granted for this version to appear in e-Publications@Marquette. Elsevier does not grant permission for this article to be further copied/distributed or hosted elsewhere without the express permission from Elsevier. 